\title{
金属スラグを骨材とした石炭灰コンクリートの 品質と配合設計手法
}

\author{
齊藤 $\quad$ 直 $1 \cdot$ 浜田純夫 $2 \cdot$ 松尾栄治 $3 \cdot$ 福留和人 4 \\ 1正会員 中国電力侏土木部石炭灰有効活用プロジェクト副長（テ730-8701 広島市中区小町4-33） \\ 山口大学大学院 理工学研究科博士後期課程（テ755-8611 宇部市常盤台 $2 丁$ 目 16 番 1 号) \\ ${ }^{2}$ 正会員 Ph. D. 山口大学教授 工学部社会建設工学科（广755-8611 宇部市常盤台 2 丁目 16 番 1 号） \\ 3 正会員 博士 (工学) 山口大学助手 工学部社会建設工学科（テ755-8611 宇部市常盤台 $2 丁$ 目16番1号) \\ ${ }^{3}$ 正会員 博士(工学) 侏間組 技術研究所主任研究員（テ305-0822 つくば市苅間字西向515-1）
}

\begin{abstract}
石炭火力発電所から産出される石炭灰は, 環境負荷低減の観点からその有効利用が重要な課題となって いる．筆者らは金属スラグおよび石炭灰を多量に用いた高密度の硬化体に関する研究・開発を進めてきた. 各種金属スラグを混入した石炭灰硬化体は，石炭灰が有する振動締固めに優れる性質 ${ }^{1}$ を活用することで， 従来のコンクリートと同等の強度を確保しつつセメント量が半減でき，金属スラグの混入量により任意の 密度が得られる. 本研究では, 締固めエネルギー量および骨材混入量から適切な配合設計が可能なこと, 凍結融解を生じない無筋コンクリートへの適用に当たって，十分な耐久性が得られることなどを明らかに した.
\end{abstract}

Key Words : coal ash, metal slag, vibrating compacition, optimum water content, mix design

\section{1. まえがき}

近年, エネルギー源の多様化の推進, 電力需要の 增加を背景として，供給の安定性および経済性に優 れた石炭火力発電所の建設が推進されている。その 結果，発電に伴う副産物である石炭灰の発生量は飛 羅的に増加し，2,010 年には全国で年間 1,000 万卜 ンを超える規模に達すると予測されている ${ }^{2)}$.これ まで，石炭灰は主にセメント原料やコンクリート用 混和材などへ有効利用されてきたが，現状でも約 $40 \%$ が管理型産業廃棄物として埋立処分されている. また有効利用のうち，約 $70 \%$ は粘土代替を中心と するセメント原料への利用であり, 今後発生量が増 大する状況の中で，その他の有効利用方法の拡大が 重要な課題となっている ${ }^{3)}$.

このような背景から, 石炭灰のうち最も発生比率 の高い微粉炭灰の原粉（広義でのフライアッシュ， 以下「石炭栃原粉」と称す）を多量に用いた技術開 発が盛んに行われており，コンクリート材料への有 効利用についても多数の研究がなされている.

従来からの石炭厕のコンクリート材料への有效利 用技術は，JIS A 6202 で規定されているフライア
ッシュ（以下，単純に「フライアッシュ」と称す） を活用したものであった. しかし， 1, 999 年の JIS 改訂によりフライアッシュの種類の設定と品質改定 が行われ，用途拡大に向けての動きが生じている ${ }^{4)}$.

石炭圧原粉をコンクリートに大量活用する場合, ワーカビリティーと強度を同一配合内に共存させる ことが困難であることに問題がある. スランプ等の 指標で表現されるコンクリートのワーカビリティー は水粉体比とは比例関倸にあり, 逆に必要品質であ る強度と水粉体比とは逆比例関係にある. 通常の工 事で用いられる $8 \sim 12 \mathrm{~cm}$ 程度の有スランプコンク リートにおいて, 両者の両立が行えないが故にフラ イアッシュの配合量はセメント量の内割 $30 \sim 40 \%$ が限界点となっていた ${ }^{5}$. 今回の JIS 改訂において も, 発電所において分級した極細粉などの高品質な フライアッシュ I 種についてのみ, 使用枠が $40 \%$ に拡大されるにとどまっている ${ }^{6}$.

一方， RCD 工法などのダムコンクリートは， 0 〜 低スランプコンクリートであり，セメントの内割 $50 \%$ 程度のフライアッシュが活用されているなど, 締固め度の向上により, 石炭灰原粉の特性を活かす ことが可能である. 


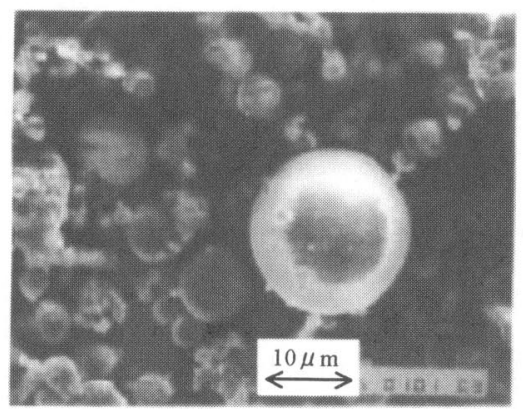

写真-1＼cjkstart石炭灰の電子顕微鏡写真

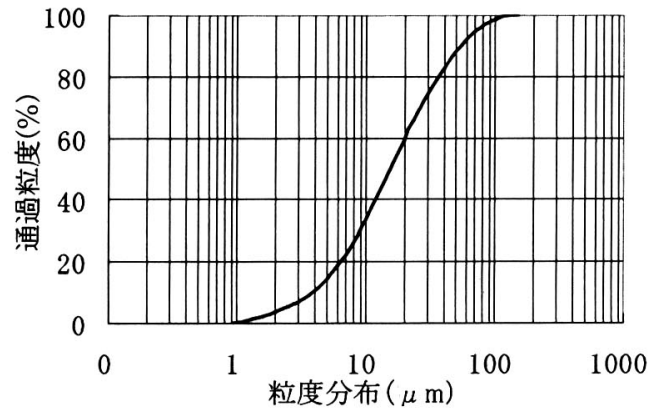

図-1 石炭灰の粒度分布の一例

石炭灰原粉は，写真-1 および図-1 に示すとおり， 土質分類ではシルト〜粘土の粒度分布を有する球形 の微粒子である. 一方，石炭灰のコンシステンシー は，液性限界・塑性限界ともにノンプラスティック (NP）であるなど，砂の性質を有しており，締固め 性能のよい粒度分布を持っていることから，人工的 に作られた微細な砂とみなすことができる。このよ うな，石炭灰原粉の持つ高い楴固め特性に着目した 有効利用技術が多数開発され，既に一部が実用化さ れている ${ }^{1), 7) \sim 10) . ~}$

特に, コンクリートに代わる新しい材料として, 石炭灰原粉を大量に使用したフライアッシュ硬化体 は，コンクリートブロックに代わる可能性を持つリ サイクル技術である ${ }^{1)}$ 。これは石炭灰原粉を活用し た技術であり，JIS 規定されているコンクリート用 フライアッシュとの誤解を防ぐため，本稿では「石 炭灰硬化体」という.

この石炭灰硬化体の密度は，使用する石炭灰原粉 の密度および水粉体比によって決定されるが， 1.7 １.9 の範囲にある ${ }^{1)}$. この值は, コンクリートや 天然骨材と比較すると小さいものであり，海洋構造 物のコンクリートとして利用する場合，荷重の影響 が少ない海底魚礁などへの適用は可能であるが，波 浪などの外力の影響を大きく受ける場所への適用は 困難である，そのため，現状では，比較的水深が深

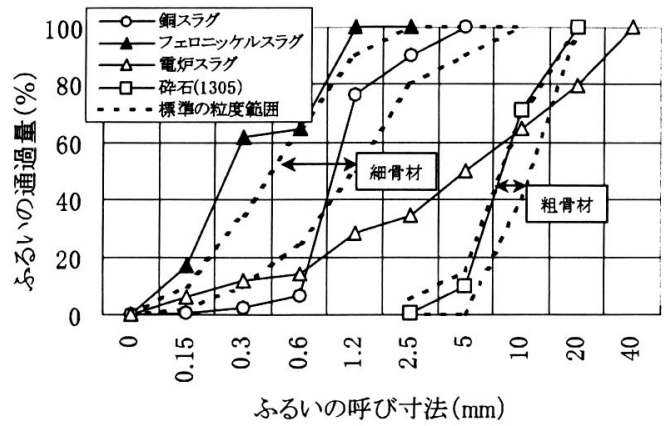

図-2＼cjkstart各骨材のふるい分け曲線

く，波浪の影響の少ない箇所への適用を前提として いる. よってこの石炭灰硬化体の密度を任意に増加 させることできれば，適用範囲を大きく拡大できる．

以上のことを踏まえ, 本研究では, 石炭灰原粉の 持つ「微細で球形で締固め性能の良い粒子」の特性 を活かし， $0 \sim 3 \mathrm{~cm}$ 程度の低スランプを対象とし た石炭灰原粉を主材とした石炭灰硬化体の海洋構造 物一の適用性の拡大を図ることを目的として，密度 の制御方法を検討した。密度制御には，産業副産物 の有効利用という観点から，密度の大きい金属スラ グを骨材として混入し重量増加を行った。

この石炭灰硬化体は密度の向上が強度に大きく影 響することから，フレッシュ性状の評価は締固め度 を中心とした土質工学的指標を用い, 硬化後の特性 評価はコンクリート工学的な観点から検討を行った. このため本論文中では, 水と粉体の質量比について, フレッシュ性状の評価のみ「含水比」，その他につ いては「水粉体比」という用語で表現する.

石炭灰を多量に用いる場合には振動による締固め が必要となる．また，金属スラグとの混合の際には 振動締固めを適用すると材料分離の可能性も生じる. そこで骨材混入量が石炭灰硬化体（ペース卜部分） の振動締固め特性に及ぼす影響, および硬化後の物 性に及ぼす影響を明らかにした。

また, 硬化体の要求密度, 振動締固め特性などを 基にした配合設計方法を提案した。

\section{2. 使用材料}

骨材には，石炭灰が軽量であるため重量化を図る 目的で，また産業副産物の有効利用の観点から，金 属を精鍊する際に副産される溶融スラグを用いた. 選定に際しては, 少ない混入量で硬化体の密度が得 られること，すなわち，スラグ自身の密度が大きい こと，膨張などの悪影響を生じないことを考慮した。 
表-1 各骨材の物理性状

\begin{tabular}{|c|c|c|c|c|c|c|c|c|c|c|}
\hline \multirow{2}{*}{ 種類 } & \multicolumn{2}{|c|}{ 密度 $\left(\mathrm{g} / \mathrm{cm}^{3}\right)$} & \multirow{2}{*}{$\begin{array}{c}\text { 吸水率 } \\
(\%)\end{array}$} & \multirow{2}{*}{$\begin{array}{c}\text { 実積率 } \\
(\%)\end{array}$} & \multirow{2}{*}{ 粗粒率 } & \multirow{2}{*}{$\begin{array}{c}\text { 微粒分 } \\
(\%) \\
\end{array}$} & \multicolumn{4}{|c|}{ 化学成分（\%) } \\
\hline & 絶乾 & 表乾 & & & & & $\mathrm{Fe}_{2} \mathrm{O}_{3}$ & $\mathrm{CaO}$ & $\mathrm{MgO}$ & $\mathrm{SO}_{3}$ \\
\hline 銅スラグ & 3.56 & 3.58 & 0.32 & 56.8 & 3.17 & 0.32 & 55.9 & 1.7 & 1.5 & 1.0 \\
\hline フェロニッケルスラグ & 3.07 & 3.08 & 0.26 & 58.7 & 1.57 & 17.0 & 7.4 & 5.8 & 28.1 & 0.2 \\
\hline 電师スラグ & 3.44 & 3.46 & 1.05 & 61.9 & 5.11 & 6.18 & 30.9 & 20.8 & 4.0 & 0.3 \\
\hline 砕石 & - & 2. 69 & 0.76 & 56.2 & 6.18 & - & - & - & - & - \\
\hline
\end{tabular}

表-2 各石炭灰の物理性状

\begin{tabular}{|c|c|c|c|c|c|c|c|c|c|c|c|c|}
\hline \multirow{2}{*}{$\begin{array}{l}\text { 種 } \\
\text { 類 }\end{array}$} & \multirow{2}{*}{$\begin{array}{c}\text { 密度 } \\
\left(\mathrm{g} / \mathrm{cm}^{3}\right)\end{array}$} & \multirow{2}{*}{$\begin{array}{c}\text { 比表面積 } \\
\left(\mathrm{cm}^{2} / \mathrm{g}\right)\end{array}$} & \multirow{2}{*}{$\begin{array}{l}\text { 湿分 } \\
(\%)\end{array}$} & \multirow{2}{*}{$\begin{array}{c}\text { 最適含水比 } \\
(\%) *\end{array}$} & \multirow{2}{*}{$\begin{array}{l}W_{140} \\
(\%) * *\end{array}$} & \multicolumn{7}{|c|}{ 化学成分（\%） } \\
\hline & & & & & & 強熱减量 & $\mathrm{SiO}_{2}$ & $\mathrm{Al}_{2} \mathrm{O}_{3}$ & $\mathrm{Fe}_{2} \mathrm{O}_{3}$ & $\mathrm{Ca} 0$ & $\mathrm{MgO}$ & $\mathrm{SO}_{3}$ \\
\hline F1 & 2.30 & 3,320 & 0.14 & 22.0 & 29.2 & 3.04 & 59.1 & 23.2 & 3.0 & 5.4 & 1.1 & 0.1 \\
\hline $\mathrm{F} 2$ & 2. 19 & 3,560 & 0.30 & 24.7 & 30.3 & 3. 30 & 64.0 & 25.2 & 3.5 & 1. 7 & 0.9 & 0.3 \\
\hline F3 & 2. 18 & 3,050 & 0.20 & 24.8 & 32.3 & 2. 10 & 57.8 & 31.1 & 4. 4 & 1. 3 & 0.7 & 0.5 \\
\hline \multicolumn{13}{|c|}{$\begin{array}{l}\text { *) 最適含水比は JIS A } 1210-1979 \text { 突固めによる土の締固め試験方法による. } \\
\text { **) フロー値比が } 140 \% \text { となる水粉体比 } \\
\text { *) **) セメント添加率 } C /(C+F)=15 \% \text { セおける測定值 }\end{array}$} \\
\hline
\end{tabular}

その結果, 電気炉の酸化スラグ（以下，「電炉ス ラグ」と称す），銅スラグおよびフェロニッケルス ラグの 3 種類を骨材として選定し，比較のために天 然骨材（硬質砂岩砕石，最大寸法 $15 \mathrm{~mm}$ ）を用いた。 使用したこれらのスラグは，実用化を前提として低 コストの材料であるよう，粒度調整をしない排出時 点での平均的な粒度構成のまま使用した。

表-1 に使用した骨材の品質を, 図-2 に骨材の粒 度分布を土木学会の標準粒度 ${ }^{11)}$ と比較して示す. 粒 度分布からは，銅スラグとフェロニッケルスラグは 細骨材，電炬スラグは粗骨材と細骨材の合成粒度に 分類される.また，電炉スラグは表面に微細な凹凸 を多数有することから，吸水率が非常に大きい骨材 である. 本研究では対象とする石炭灰硬化体をぺー ストと骨材の二層材料と捉えるため，これらを総じ て骨材と称す. また, 使用した石炭灰原粉は, 中国 電力怢)の新小野田火力発電所で採取された 3 種類の 石炭灰原粉（以下 F1〜F3 と称す）を用いた. 表-2 に石炭灰の品質を示す.フレッシュ性状の実験にお いては，石炭灰の品質変動の影響を避けるため，F1 の 1 種類で実験を行い，強度性状に関する実験にお いては，石炭灰種類の違いによる影響も調べた。

セメントは, 普通ポルトランドセメント（密度 $3.16 \mathrm{~g} / \mathrm{cm}^{3}$, 比表面積 $\left.3,280 \mathrm{~cm}^{2} / \mathrm{g}\right)$ とし, その量を 結合材（石炭灰とセメント）の内割りで $15 \%$ と一 定にした。 また，硬化促進剤として $\mathrm{NaCl}$ を用い， 予め練混ぜ水に溶解した。濃度は海水による練混ぜ を想定して，水の質量に対して $3.3 \%$ と一定にした。 表-3＼cjkstart振動締固め試験における実験要因と水準

\begin{tabular}{|c|c|c|}
\hline \multicolumn{2}{|c|}{ 実谸要因 } & 水潅 \\
\hline \multirow{5}{*}{$\begin{array}{c}\text { 骨材の種類 } \\
\text { およひ } \\
\text { 混入量 } \\
\left(\mathrm{l} / \mathrm{m}^{\mathrm{s})}\right. \\
\text { ※下尉 : } \\
\text { 混入率 } \\
(\%)\end{array}$} & 銅スラグ & $\begin{array}{ccc}341, & 454, & 568 \\
(60), & (80), & (100)\end{array}$ \\
\hline & 裡妒スラグ & $\begin{array}{lll}300, & 400, & 500 \\
(50), & (65), & (80)\end{array}$ \\
\hline & $\begin{array}{l}\text { フェロニッ } \\
\text { ケルスラグ }\end{array}$ & $\begin{array}{rr}352,470, & 587 \\
(60), & (80), \quad(100)\end{array}$ \\
\hline & 碎石 & $\begin{array}{ccc}337, & 450, & 562 \\
(60), & (80), & (100)\end{array}$ \\
\hline & $\begin{array}{l}\text { 鎆スラグ } \\
\text { +碎石 }\end{array}$ & $\begin{array}{ccc}452, & 565, & 678 \\
(40+40), & (50+50), & (60+60)\end{array}$ \\
\hline \multirow{3}{*}{ 振動条件 } & 振幅 & 1. $0 \mathrm{~mm}$ （両振幅） \\
\hline & 振動数 & $33.3,50.0,66.7 \mathrm{~Hz}$ \\
\hline & 振動時間 & $3,5,8,12$ 分 \\
\hline
\end{tabular}

\section{3. 実験方法}

\section{（1）振動締固め}

骨材の種類および混入量は，骨材を除くペースト 部分の最適水粉体比，および得られる密度に大きな 影響を及ぼす．よってこれらが振動締固め特性（最 適含水比 $\omega_{\text {opt }}$ および最大乾燥密度 $\gamma_{d \cdot \max }$ ）に及ぼす 影響を明らかにするとともに，振動条件（周波数お よび振動時間などの振動エネルギー）が振動締固め 特性に及ぼす影響を把握することを目的とした。す なわち，表-3 に示す骨材混入量，振動条件をパラ メターとして，振動締固め特性に及ぼす影響を調べ た. 


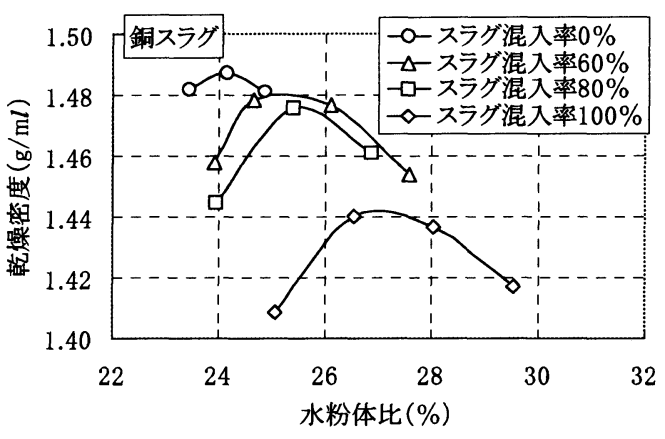

図-3 水粉体比と乾燥密度の関係（銅スラグ）

表-4 強度試験における実験要因と水準

\begin{tabular}{|c|c|c|}
\hline \multicolumn{2}{|c|}{ 実酸要因 } & 水潐 \\
\hline \multirow{4}{*}{$\begin{array}{c}\text { 骨材の種類 } \\
\text { および } \\
\text { 混入量 } \\
\left(l / \mathrm{m}^{3}\right) \\
\text { ※下段 : } \\
\text { 混入率 } \\
(\%)\end{array}$} & 鏩スラグ & $\begin{array}{ccc}341, & 454, & 568 \\
(60), & (80), & (100) \\
\end{array}$ \\
\hline & 電炉スラグ & $\begin{array}{lll}300, & 400, & 500 \\
(50), & (65), & (80)\end{array}$ \\
\hline & 研石 & 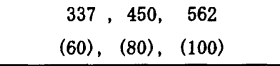 \\
\hline & $\begin{array}{l}\text { 䇠スラグ } \\
\text { +碎石 }\end{array}$ & $\begin{array}{ccc}452, & 565, & 678 \\
(40+40), & (50+50), & (60+60)\end{array}$ \\
\hline \multirow{3}{*}{ 掁動条件 } & 振愊 & $1.0 \mathrm{~mm}$ (両振幅) \\
\hline & 振版数 & $33.3,50.0,66.7 \mathrm{~Hz}$ \\
\hline & 掁功時間 & $3,5,8,12$ 分 \\
\hline \multicolumn{2}{|c|}{ 石炭灰原粉の種類 } & F1, F2, F3 \\
\hline \multicolumn{2}{|c|}{ 水粉体比: $W /(C+F)$} & 試酸で得られた最道含水比 \\
\hline \multicolumn{2}{|c|}{ セメント添加率: $C /(C+F)$} & $10,15,20,25 \%$ \\
\hline \multicolumn{2}{|c|}{ 堆生温度 } & $20^{\circ} \mathrm{C}$ \\
\hline
\end{tabular}

表-5 実験項目と実験方法

\begin{tabular}{|c|c|}
\hline 测定項目 & 測定方法 \\
\hline 単位容積質量 & $\begin{array}{c}\text { 圧縮強度試験直前に, 気中重量 } \\
\text { および水中重量を測定 }\end{array}$ \\
\hline 圧縮強度 & $\begin{array}{c}\text { JIS A } 1108 \text { に準拠 }\left(20^{\circ} \mathrm{C}\right) \\
\text { 材鯩：7，8，28 および } 91 \text { 日 }\end{array}$ \\
\hline 圧縮強度 & 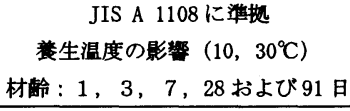 \\
\hline ヤング係数 & $\begin{array}{c}\text { コンプレッソメーターによる } \\
\text { 材齢 : } 28 \text { および } 91 \text { 日 }\end{array}$ \\
\hline ポアソン比 & エキソテンソメーターによる \\
\hline 引張強度 & JIS A 1113 に準挟 \\
\hline 長さ変化 & $\begin{array}{l}\text { JIS A } 1129 \text { に淮扰 } \\
\left(20^{\circ} \mathrm{C} \text {, 湿度 } 60 \%\right)\end{array}$ \\
\hline 耐糜耗性 & $\begin{array}{l}\text { JIS K } 7204 \text { 摩耗輪法 } \\
500,1000 \text { 回転で測定 }\end{array}$ \\
\hline
\end{tabular}

骨材混入量は, 実積率に相当する骨材量すなわち $1 \mathrm{~m}^{3}$ 当たり「実積率 $\times 10 l$ 」を最大として 3 水準変化 させた. 振動条件として, 振動数を 3 水準 (33.3,
50.0 および $66.7 \mathrm{~Hz})$ ，振動条件を 4 水準（3，5， 8 および 12 分）に変化させた. 振幅は $1.0 \mathrm{~mm}$ (両 振幅）で一定とした.

練混ぜは, 容量 $5 l$ のモルタルミキサーを用いた. 粉体量が非常に多いことから，混合の不均一性によ る影響を及ぼさないよう，空練りを低速で 30 秒， 塩水投入後に高速で 150 秒の合計 180 秒間の十分な 練混ぜを行った.

JIS A 1210-1979「突固めによる土の締固め試 験」で使用される型枠 (内径 $100 \mathrm{~mm}$, 容積 1,000ml) を大型 VC (Vibration Compaction) 試験 装置の振動台に固定し, 振動による締固めを行い, 表面を平滑にならした後, 質量を測定した。乾燥密 度の最大值が得られるように水粉体比を変化させて 繰り返し試験を行った. 図-3 に示すように最大值 を含む乾燥密度の測定值 $3 \sim 4$ 点を 2 次曲線で近似 し，ピーク位置および高さをそれぞれ最適含水比お よび最大乾燥密度とした。ここで, 乾燥密度は骨材 を除いたペースト部分の乾燥密度 $\gamma_{d}$ とし, 質量と 示方配合から式(1)によって算出した.

$$
\gamma_{d}=\frac{\omega(C+F) /(W+C+F+G)}{1000-\omega \cdot G /(W+C+F+G)}
$$

$$
\begin{aligned}
& \text { ここで, } \omega: \text { 試料の質量 }(\mathrm{g}) \\
& W, C, F, G: \\
& \text { それぞれ水, セメント, 石炭灰原粉 } \\
& \text { および骨材の単位量 }\left(\mathrm{kg} / \mathrm{m}^{3}\right)
\end{aligned}
$$

\section{(2) 強度および変形}

骨材混入量および振動条件が締固め特性に及ぼす 影響を明らかにした後、これらの条件が強度特性に 及ぼす影響の評価を目的に実験を行った，強度に影 響を及ぼすと考えられる密度は，一定の振動エネル ギーにおいて骨材の混入量により変化することとな る.このため, まず骨材の混入量を変化させて密度 への影響を調べた.

また，硬化の主原料となるセメント量を変化させ た場合の強度性状を調べた。ここで，対象とした骨 材は, 微粉分が多く振動締固め特性への影響の大き いフェロニッケルスラグを除いた骨材とし，骨材の 混入が強度へ及ぼす影響を調べることを目的とした。

練混ぜは, 容量 $50 l$ のパン型強制練りミキサーを 用い, 空練りを低速で 30 秒, 塩水投入後, 高速で 150 秒と合計 180 秒閒の十分な練混ぜを行った.

表-4 に，実験要因および水準を示す．石炭灰原 粉の種類, セメント添加率, 骨材種類および混入量, 


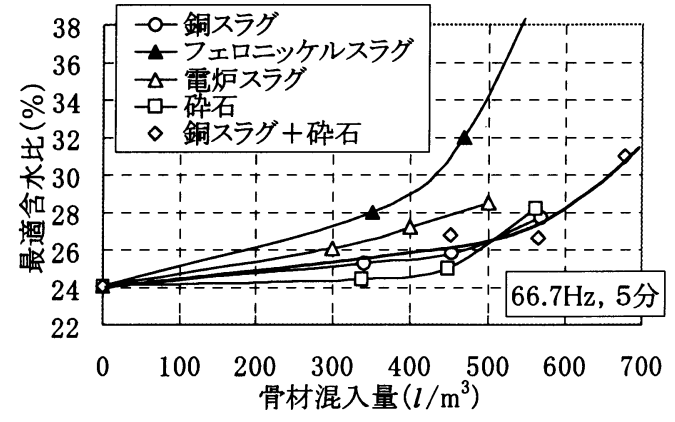

図-4 骨材混入量と最適含水比の関係

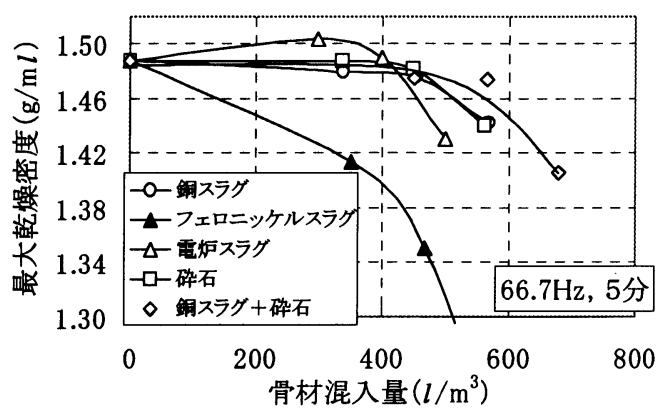

图-5 骨材混入量と最大乾燥密度の関保

振動締固め条件を種々変化させて硬化後の物理的性 質に及ぼす影響を調べた。ここで，各条件における 水粉体比は, 振動締固め特性から得られた最適含水 比とした. さらに, 暴露試験における長さ変化, す りへり抵抗性などを実験的に求め, 発錆状況の観察 結果もあわせて耐久性評価を行った.

以上の実験項目および方法を表-5 にまとめて示 す. 養生方法は, 標準水中養生 $\left(20 \pm 2{ }^{\circ} \mathrm{C}\right)$ とした.

\section{4. 実験結果および考察}

\section{(1) 振動締固め}

\section{a) 骨材種類および混入量の影響}

まず，振動条件一定（振動数 $66.7 \mathrm{~Hz}$ ，振動時間 5 分）で骨材の種類および混入量を変化させ, 締固 め特性に及ぼす影響を調べた。 図-4に骨材混入量 とペースト部分の最適含水比の関係を，図-5に骨 材混入量とペースト部分の最大乾燥密度の関係を示 す.

骨材混入量の増加に伴い最適含水比は直線的に増 加し，ある量を超えると急激に増加する傾向がある。 逆に最大乾燥密度は直線的に減少し，ある量を超え ると急激に減少する傾向が確認できる．この変化の

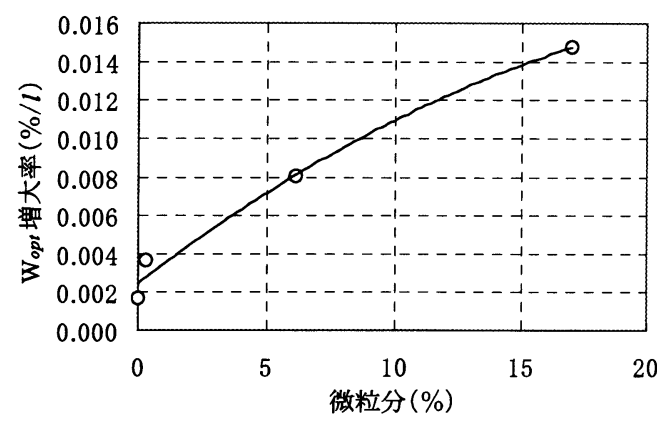

図-6 微粉分量と最適含水比の増大率の関俰

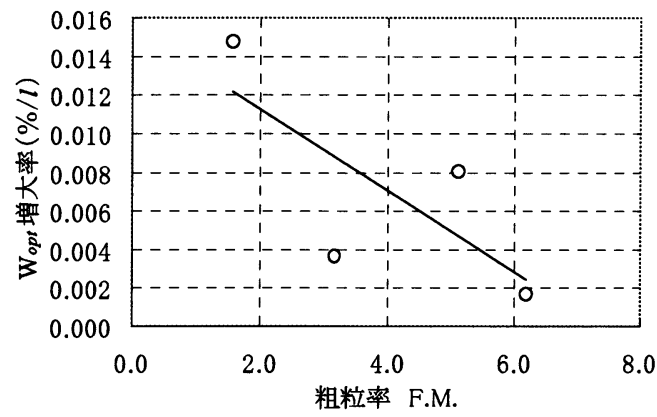

図-7 粗粒率と最適含水比の增大率の関係

程度は骨材種類によって異なり，銅スラグ，電炉ス ラグおよび砕石の場合, 実積率の $80 \%$ に相当する 骨材量 $\left(450 \sim 500 l / \mathrm{m}^{3}\right)$ 程度までは最適含水比に大 きな増加はみられないが，フェロニッケルスラグの 場合, 混入量が小さい段階から最適含水比は大幅に 増加し最大乾燥密度は大幅に減少する結果となった.

フェロニッケルスラグを使用した場合に, 他のス ラグと比較して密度が大きくならない理由として, 骨材粒子の径の影響が考えられる. そのため, 最適 含水比の增大が直線的な範囲（骨材量 $500 l$ 以下） を直線近似し, 直線の勾配 (以下「最適含水比増大 率」と称す）を算出し, 骨材の微粒分量 $(150 \mu \mathrm{m}$ 以下）および粗粒率との関係を求めた.

図-6〜7 に微粒分量および粗粒率と最適含水比増 大率の関係を示すが, 微粒分量が大きいほど, また 粗粒率が小さいほど最適含水比増大率は大きくなる. 骨材混入による最適含水比の増大は, 振動締固め時 の骨材同士の干涉が生じてペースト部分の締固めの 進行を阻害すること, 微細な骨材の表面に保水され 見かけ上の水粉体比が低減することによると考えら れる. すなわち，一般的なコンクリートと同様に骨 材の混入によってコンシステンシーが増大するため, 締固めに要するエネルギーが増大すると考えられる. また，粒径の異なる銅スラグと砕石を併用すれば， 


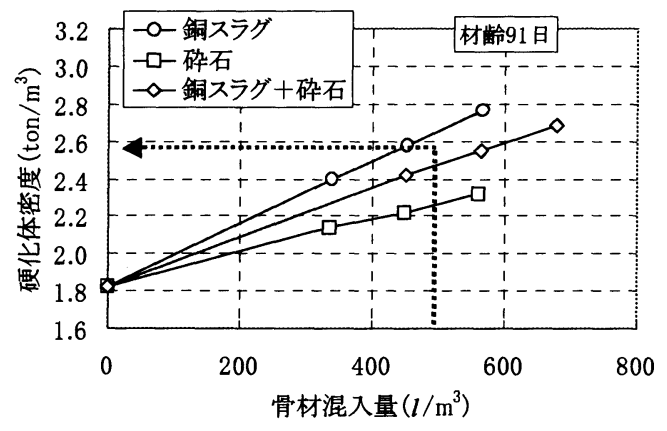

図-8 骨材混入量と硬化体密度の関係

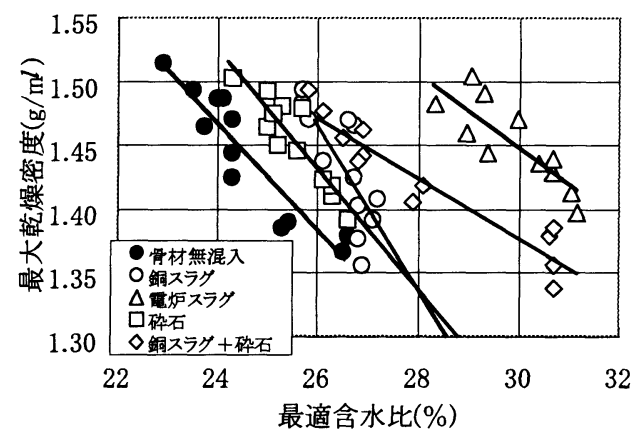

図-9 最適含水比と最大乾燥密度の関俰

実積率が大きくなるため, 最適含水比が大幅に増大 し始める骨材混入量の值を増加することができる.

以上のように骨材混入によって最適含水比の増大 が見られるが, 微粉分の多いフェロニッケルスラグ を除けば，実積率に相当する骨材量の $70 \%$ （393〜 $\left.433 \mathrm{l} / \mathrm{m}^{3}\right)$ 程度の量であれば, 最大乾燥密度の低下も 小さく, 若干の水粉体比の補正によって良好に締固 めを行うことが可能となっている.

図-8に骨材混入量と硬化体密度の関係を示す. この図からもわかるように，図-5 で $95 \%$ 程度の最 大乾燥密度が得られる骨材量 $500 \mathrm{l} / \mathrm{m}^{3}$ から得られる 密度は $2.6 \mathrm{~g} / \mathrm{cm}^{3}$ 程度（銅スラグ混入の場合）であり， 重量コンクリートの領域と考えられる.

\section{b) 振動条件の影響}

振動条件が締固め率に及ぼす影響を明らかにする ため, 骨材量を一定とし, 振動数および振動時間を 変化させた場合の締固め率を求めた。骨材量は各骨 材で最適含水比が大幅に増大しない範囲で最大とな る骨材量で一定とした．すなわち銅スラグおよび砕 石の骨材混入量は，実積率に相当する骨材量に対し て $80 \%$ (それぞれ 454 および $449 l / \mathrm{m}^{3}$ ) とした. 電 炉スラグの場合, 微粒分の影響で最適含水比の増大 が若干大きいことから， $65 \%\left(400 \mathrm{l} / \mathrm{m}^{3}\right)$ とした。銅 スラグと砕石を混合した場合は，銅スラグを $50 \%$ ，

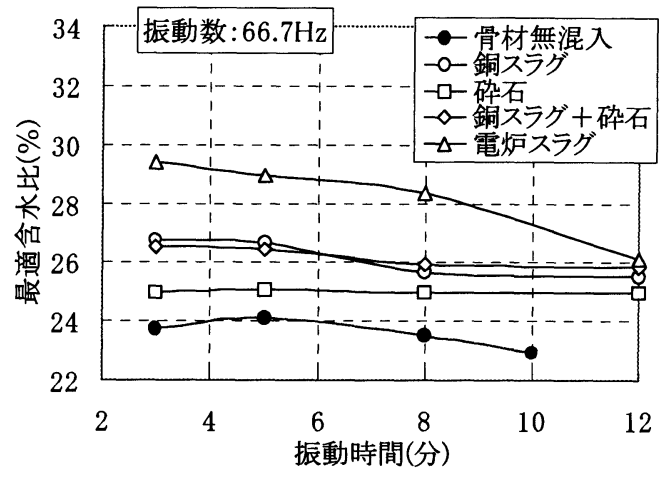

(a) $66.7 \mathrm{~Hz}$

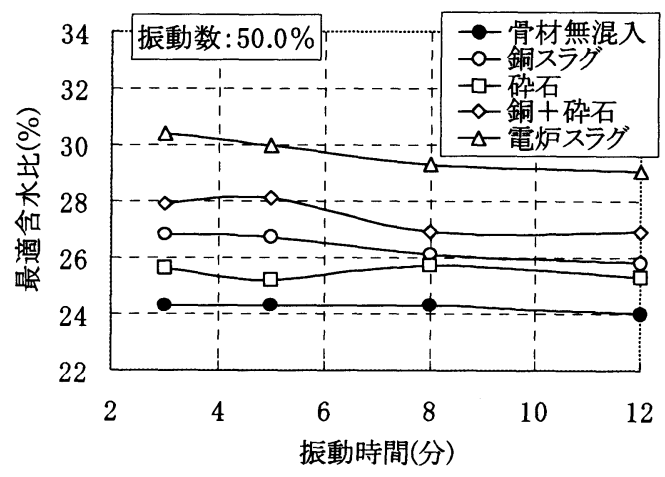

(b) $50.0 \mathrm{~Hz}$

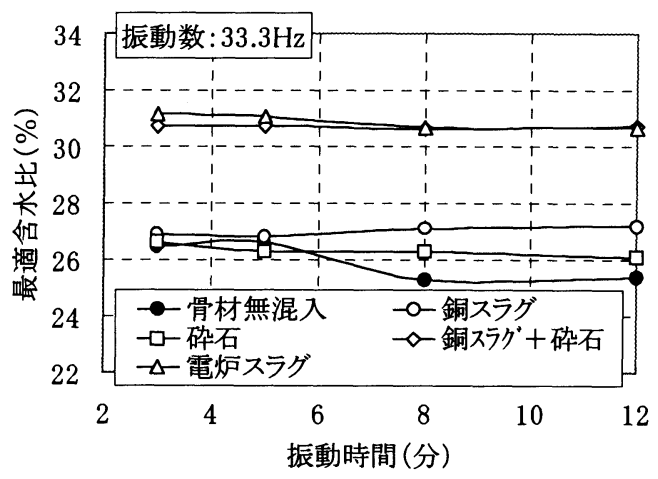

(c) $33.3 \mathrm{~Hz}$

図-10 振動時間と最適含水比の関係

砕石を $50 \%$ (それぞれ 284 および $281 / / \mathrm{m}^{3}$ ) とした。 また振動数は $33.3,50.0$ および $66.7 \mathrm{~Hz}$ とし，振動 時間は $3,5,8$ おび 12 分とした. 大型 VC 試験 装置を用い，振幅条件は両振幅 $1.0 \mathrm{~mm}$ で一定とした。

図-9 に振動条件を変化させた場合の最適含水比 と最大乾燥密度の関係を示す。また, 図-10 に振動 時間と最適含水比の関係を, 図-11 に振動時間と最 大乾燥密度の関係を示す. 


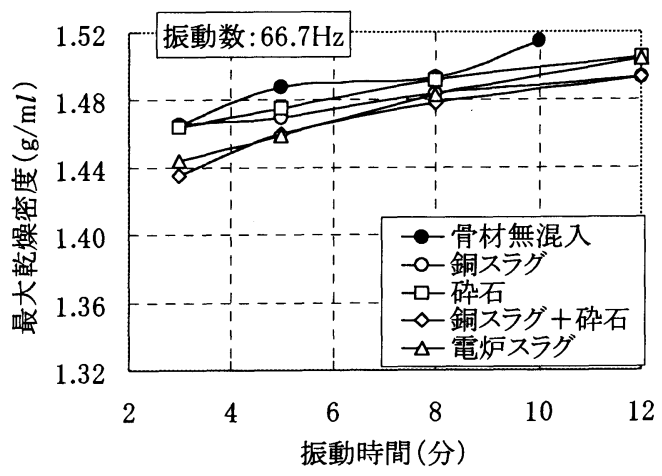

(a) $66.7 \mathrm{~Hz}$

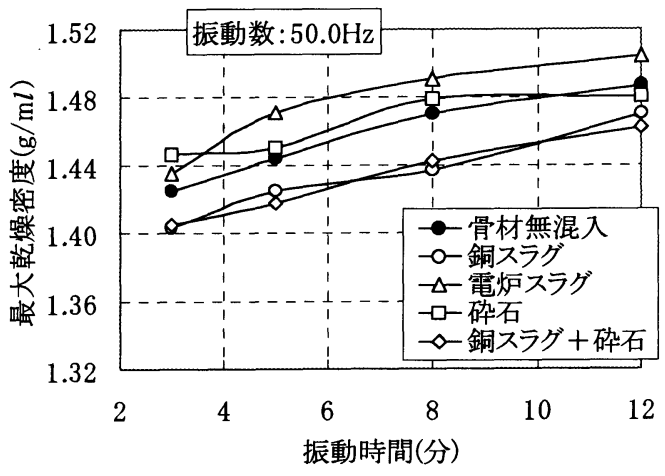

(b) $50.0 \mathrm{~Hz}$

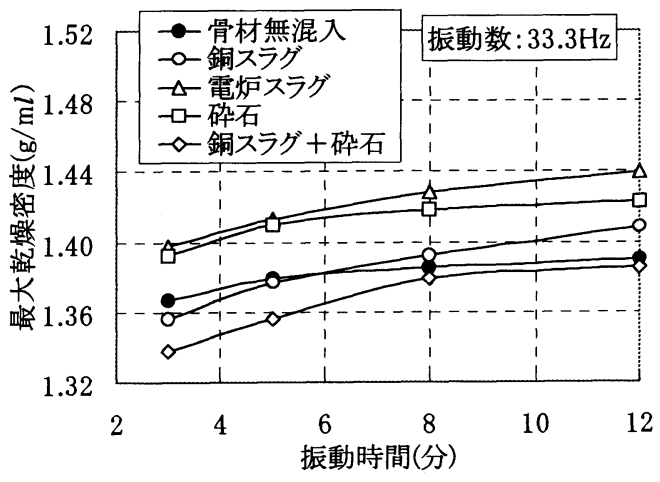

(c) $33.3 \mathrm{~Hz}$

図-11振動時間と最大乾燥密度の関係

これらの結果から，振動条件が変化するにも関わ らず，同一骨材の場合には，ペースト部分の最適含 水比と最大乾燥密度には大きな相関関係が得られる ことが明らかとなった。このことは，同一骨材を使 用した場合, ペースト部分の締固め特性を一義的に 決定することができることを表すものである.

また, 振動数の増加にともなって, 最適含水比は 低下し最大乾燥密度は増大する．また振動時間の経
過とともに最大乾燥密度は増大する. すなわち, 与 える振動エネルギーが大きくなることにより，低水 粉体比で密に締固めを行うことができる，すなわち 締固め特性が改善できると考えられる.

振動による締固め性能を定量的に評価するために, 単位容積の供試体に与える振動エネルギーを各振動 条件毎に算出し, 最適含水比および最大乾燥密度と の関係を求めた.

ここで, 単位容積あたりの振動エネルギーは, 式 (2)により求めた.

$$
E=\frac{m \cdot \alpha_{\max }{ }^{2} \cdot t}{(2 \pi)^{2} \cdot f}
$$

ここで, $E$ : 単位あたりの振動エネルギー $(\mathrm{J} / l)$

$$
f: \text { 振動数 }(1 / \mathrm{s})
$$

$t:$ 振動時間 ( $\mathrm{s}$ )

$\alpha_{\text {max }}$ : 最大振動加速度 $\left(\mathrm{m} / \mathrm{s}^{2}\right)$

$m:$ 試料の密度 $(\mathrm{kg} / l)$

図-12 に振動エネルギーと最適含水比の関係を, 図-13 に振動エネルギーと最大乾燥密度の関係を示 す.ばらつきは見られるものの, 振動数および振動 時間が異なっても使用骨材毎に一つの曲線で回帰で きることがわかる.

このことは，使用骨材を特定すれば，与える振動 エネルギーに応じて最適含水比を予測でき，また， 達成可能な締固め度（最大乾燥密度および最適含水 比）も同様に予測できることを表している.

以上の結果から, 振動条件の相違については, 式 （2）により振動エネルギーを定義することにより， 異なる振動条件においても一義的に最適含水比およ び最大乾燥密度を予測できることがわかった.

また，本実験中で最も大きな締固めエネルギー (約 $16 \times 10^{3} \mathrm{~J} / l$ ) を与えた場合を基準にすれば，そ の $95 \%$ の締固め率に相当するエネルギーはスラグ 種類によって異なり, 最小でも $5,000 \times 10^{3} \mathrm{~J} / l$ 程度 になる.

\section{(2) 強度および変形 \\ a) 圧縮強度}

図-14に骨材混入量による密度低下が少ない中央 水準における材齢と圧縮強度の関係を示す. 骨材混 入による強度低下が確認されるが, それぞれ材齢の 経過に伴う強度增進が見られ，いずれの骨材とも異 常膨張などの悪影響はなかった. 


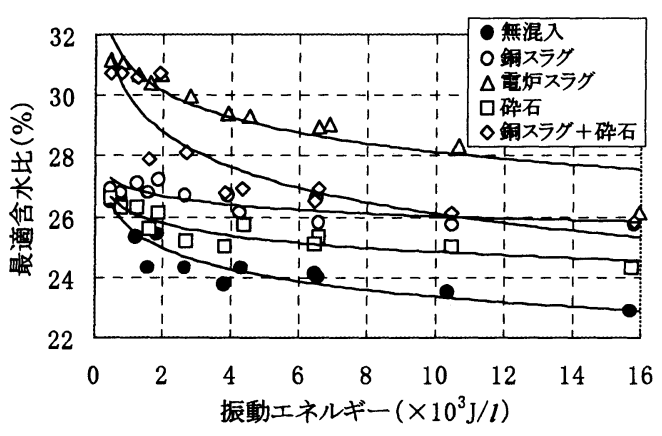

図-12 振動エネルギーと最適含水比の関係

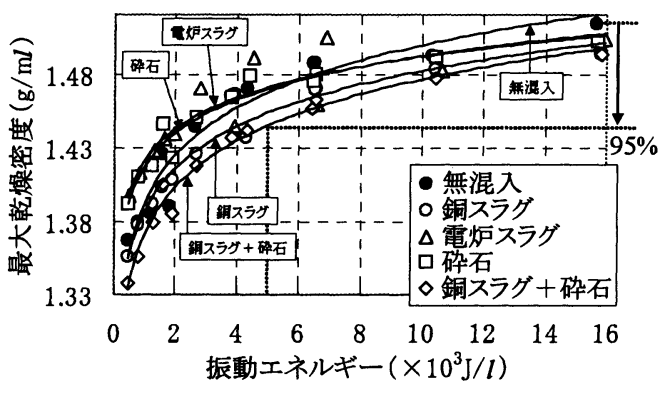

図-13振動エネルギーと最大乾燥密度の関倸

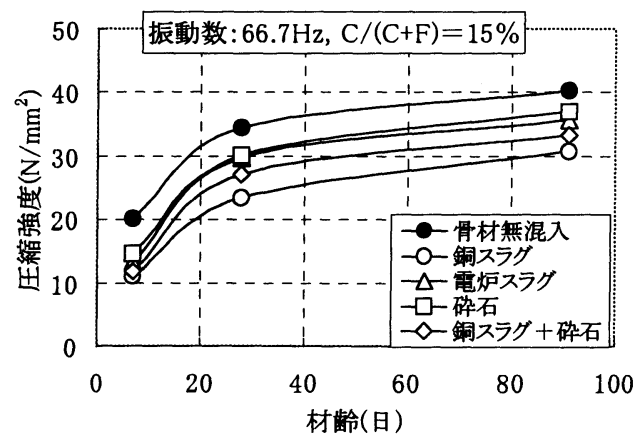

図-14 圧縮強度の経時変化

図-15に，骨材混入量と無混入の圧縮強度に対す る比の関係を材齢ごとに示す．骨材混入とともに圧 縮強度は直線的に低下しており，その低减割合は銅 スラグが大きい．また，いずれの骨材も材齢の経過 とともに強度低下率は小さくなる傾向が確認できる.

骨材混入により圧縮強度が低下する原因の一つと して, 骨材混入に伴って最適水粉体比が増大するこ とが考えられるが, 骨材混入による破壊性状の変化 が大きな理由であると考えられる.

すなわち，骨材を混入した場合，圧縮力が作用す ると骨材周囲に引張応力が生じ，付着ひび割れが進

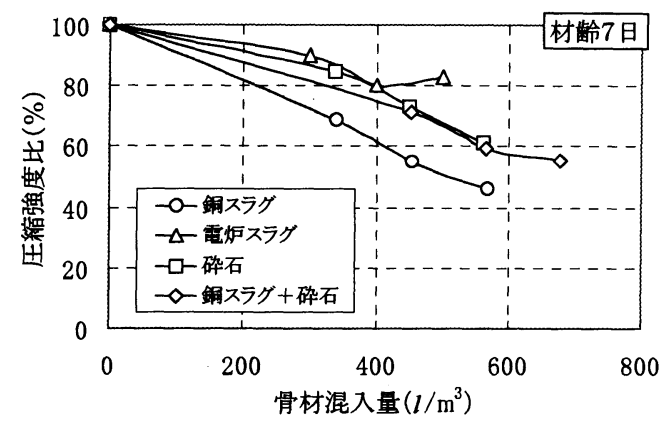

(a) 材龄 7 日

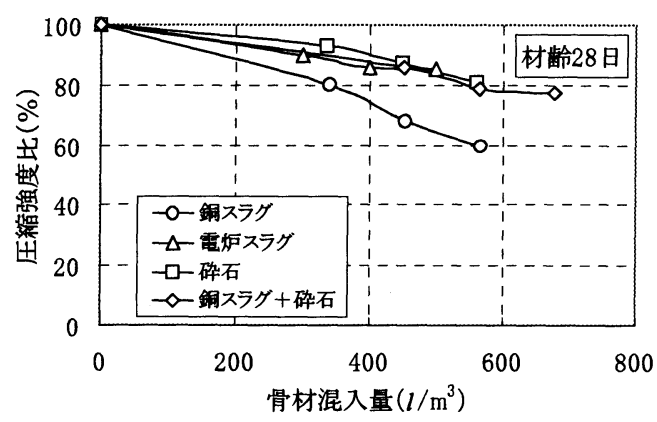

(b) 材齢 28 日

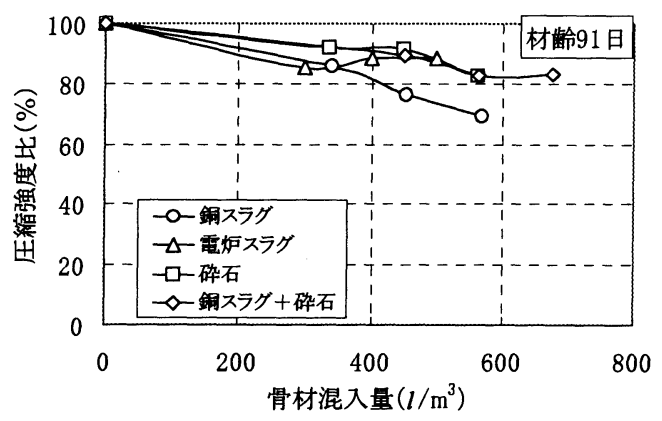

(c) 材齢 91 日

図-15 骨材混入量と圧縮強度比の関係

展する. そのため, 最大応力は付着界面の破壊で決 定されるようになり，その結果，混入量とともに強 度低下が大きくなるものと考えられる。

銅スラグの強度低下率が大きいのは，銅スラグの 微粒分が凝結遅延物質であること ${ }^{11)}$ ，表面がガラス 質で付着強度が小さいことによるものと考えられる， また, 材齢の経過に伴って強度低下率が小さくなる ことから, 水和の進行に伴って, 石炭灰のアルカリ 消費により硬化阻害物質が消散され, 界面の付着強 度が改善されることによるものと考えられる.

図-16 に振動数 $66.7 \mathrm{~Hz}$ および $33.3 \mathrm{~Hz}$ におけるセ 


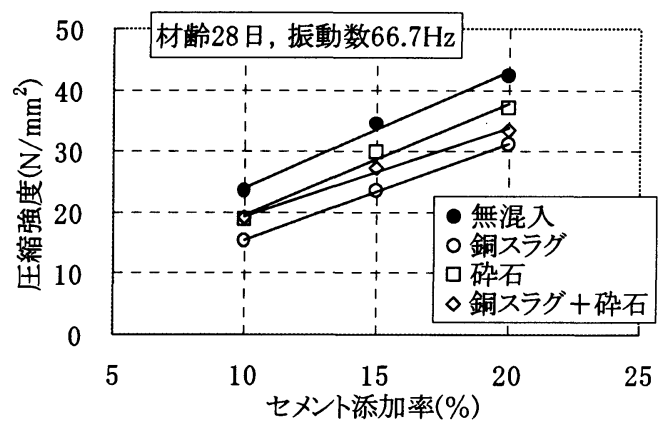

(a) $66.7 \mathrm{~Hz}$

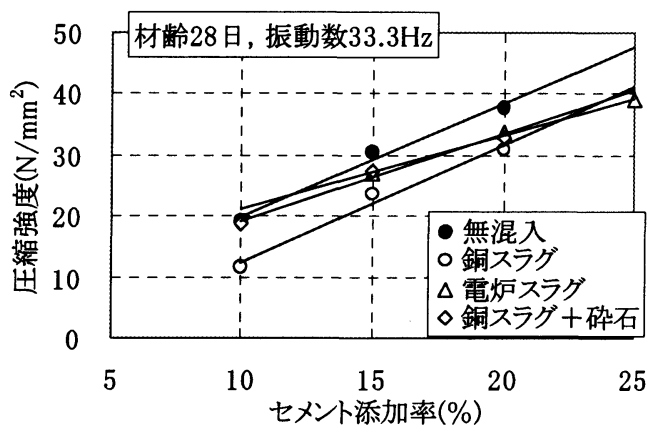

(b) $33.3 \mathrm{~Hz}$

図-16 セメント添加率と圧縮強度の関係

メント添加率と圧縮強度の関係を示す.ここで, 骨 材混入量はぞれぞれの骨材の中央水準である.

いずれの骨材を使用した場合も，セメント添加率 と圧縮強度は直線関係にある. 水粉体比の差異の影 響の評価も必要となるが，圧縮強度に及ぼすセメン 卜添加率の影響を定量評価することで，骨材の種類， 混入量に応じたセメント添加率の決定が可能となる. これらの図から, セメント添加率 $5 \%$ 程度の補正に よって $7 \sim 10 \mathrm{~N} / \mathrm{mm}^{2}$ の強度の制御ができ, 図-15(b) の骨材混入に伴う強度低下率 $20 \%$ に相当する 7 $10 \mathrm{~N} / \mathrm{mm}^{2}$ と同等であることから，骨材混入時の強度 を無混入の強度と同程度に確保できるものと判断で きる.

\section{b) 引張強度}

図-17 に圧縮強度と引張強度の関係を, 図-18に 引張強度と材齢の関係を示す.ここで，骨材混入量 は中央水準とした.

圧縮強度の場合と異なり, 引張強度は骨材混入に よって増加する. よって同一圧縮強度に対する引張 強度の割合に着目すると, 若材齢時の強度が低い場 合には，骨材無混入と骨材混入に大きな差がみられ ないが，材齢の経過に伴って，また骨材混入によっ て引張強度の割合が増加する傾向がみられる。この

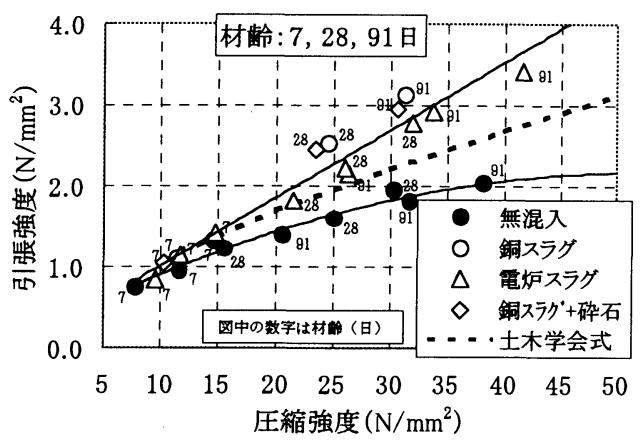

図-17 圧縮強度と引張強度の関係

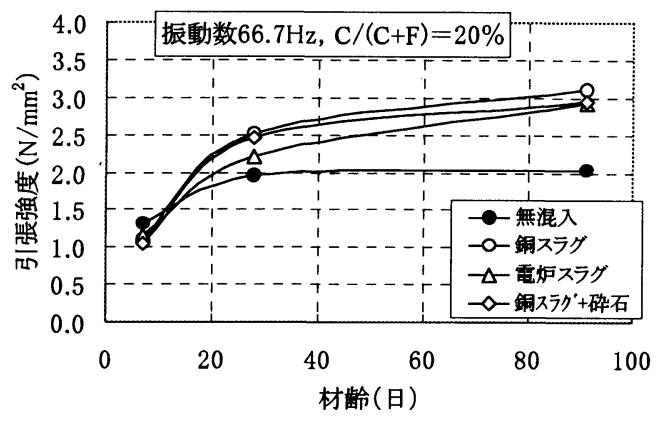

図-18 引張強度の経時変化

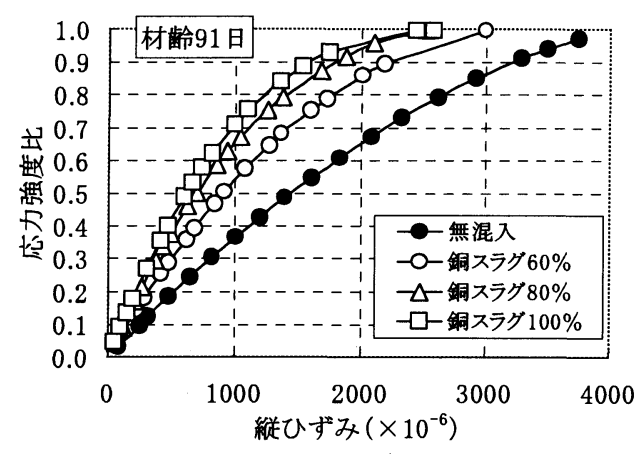

図-19 繸ひずみと応力強度比の関係

ように, 圧縮強度と引張強度で傾向が逆になる理由 については，それぞれの破壊機構の解明が必要であ り, 今後の課題である.

図-17 には土木学会標準示方書に示されている予 測式を示すが，骨材を混入したものの実測値は，ほ ぼこの値を上回っており，通常のコンクリートと同 等の引張強度を有していると考えることができる.

c) 変形特性

図-19 に応力ひずみ関係に及ぼす骨材混入の影響 の一例（銅スラグの場合）を示す．骨材混入量とと 


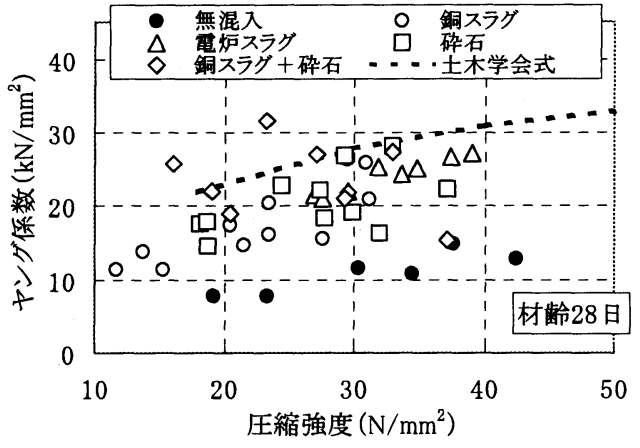

図-20 圧縮強度とヤング係数の関係

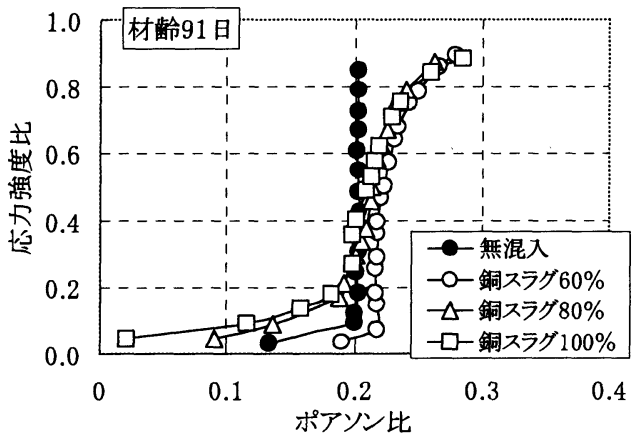

図-21 ポアソン比と応力強度比の関係

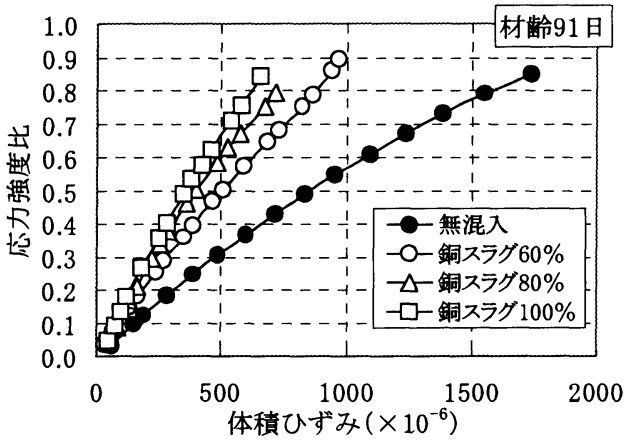

図-22 体積ひずみと応力強度比の関係

もにヤング係数が大きくなり，また，応力ひずみ関 倸の非線形性が大きくなる傾向が見られる．最大応 力時のひずみは，骨材混入量とともに小さくなって いる.

図-20 に圧縮強度とヤング係数の関係を示す．図 は，骨材混入量全水準の測定值である，骨材混入量 が異なるため広い範囲で分布しているが，同一圧縮 強度に対するヤング係数は，無混入の場合が最も小 さく，混入量が最も多くなる「銅スラグ十砕石」
（表-4 参照）の值が高くなるなど，骨材混入によ って増大する傾向がみられる.

図中に土木学会標準示方書の式を示すが，通常の コンクリートに比べて骨材量が少ないため，ほとん どの測定值がこの值を下回っている，単一種の骨材 を混入する場合には, 混入できる骨材量には自ずと 限界があり，実用に当っては，通常のコンクリート よりヤング係数は小さくなることを考慮する必要が ある。

図-21〜22に，それぞれポアソン比および体積ひ ずみと破壊強度を基準とした応力強度比の関係を示 す. ポアソン比は, 応力強度比 0.5 以下では, ほぼ 0.2 であり, 通常のコンクリートとほぼ同等である. 応力が破壊域に近づくにつれて, ポアソン比の変化 に骨材混入の影響がみられる。

無混入の場合には破壊に至るまでほぼ一定の值を 示しているのに対し，骨材を混入した場合には応力 強度比 0.6 程度からポアソン比の增大が見られる. そのため, 体積ひずみと応力強度比の関係も骨材混 入によって変化している.

以上のような変形特性の変化は，骨材混入による 破壊形態の変化によるものと考えられる．才なわち， 骨材無混入の場合は均質なペーストが硬化した材料 であるため, クラックの発生が最終的な破壊とほぼ 一致する完全脆性に近い破壊形態を示すのに対し， 骨材を混入した場合には骨材の付着界面の微細クラ ックが徐々に進行しながら破壊に至り，コンクリー 卜と同様な破壊形態となる.

このように，骨材の混入が石炭灰硬化体の脆性的 な性質を改善する上で効果的に寄与しているといえ， スラグを混入した硬化体は実用に耐え得るものと考 えられる.

\section{（3）耐久性}

a) 長さ変化

図-23に電炉スラグを用いた場合の暴露期間と収 縮ひずみの関係を示す，また，図-24に骨材混入量 と暴露期間 13 週における収縮ひずみの関倸を示す.

図に示すように骨材の混入によって長さ変化が大 幅に低减されていることがわかる．通常のコンクリ 一トに比べて骨材混入量は小さいにもかかわらず, $400 \mathrm{l} / \mathrm{m}^{3}$ 以上のスラグ混入により, 長さ変化の絶対值 は普通コンクリート（水セメント比 $55 \%$, 細骨材 率 $40 \%$, 単位水量 $150 \mathrm{~kg} / \mathrm{m}^{3}$, 減水剂はセメント量 の $0.25 \%$ ）より小さくなっている.

これは, 水粉体比が小さいため, ペースト部分の 長さ変化特性も改善されているためと考えられる. 骨材の種類によって若干差が見られるようであるが, 


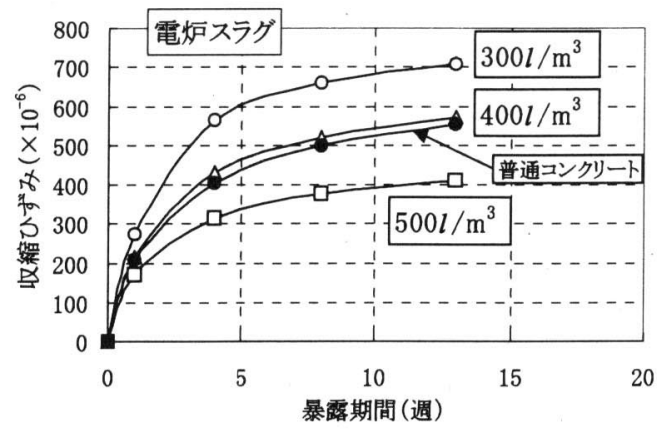

図-23長さ変化の経時変化

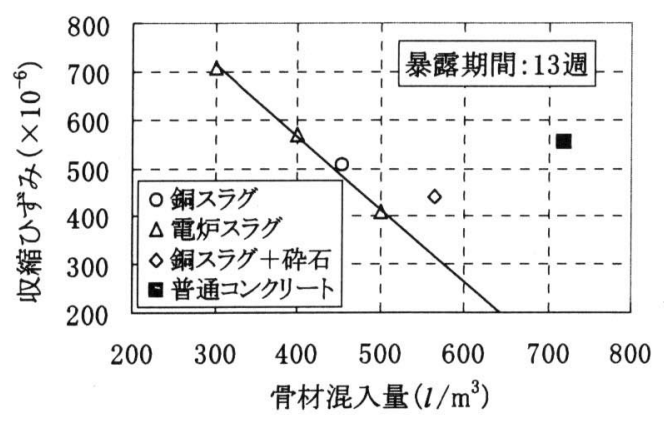

図-24 骨材混入量と長さ変化の関係

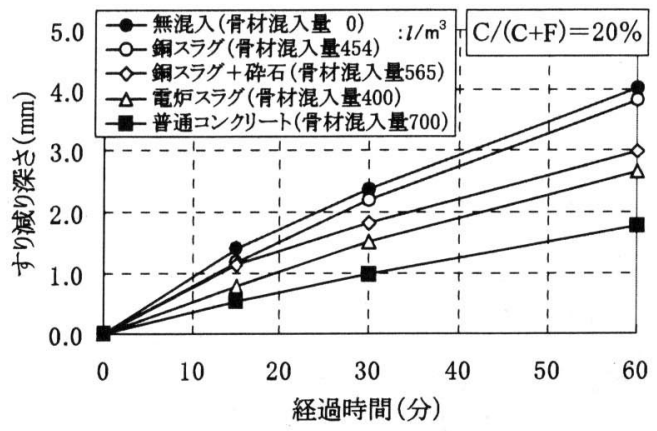

図-25すり減り深さの経時変化

骨材混入量 $400 \mathrm{l} / \mathrm{m}^{3}$ 程度以上とすれば, 通常のコン クリート程度にまで長さ変化特性を改善することが 可能である. なお，使用した電炉スラグは 5 年間自 然エージングした材料であり, $20^{\circ} \mathrm{C}$ の暴露条件にお いては体積変化の影響は少ないものと考えられる.

b)すり減りに対する抵抗性

図-25 に表-4 の中央水準の骨材混入量における骨 材種類とすり減り梁さの関係, 図-26に電炉スラグ 骨材の場合のセメント添加量とすり減り深さの経時 変化を示す．また，図-27に骨材混入量とすり減り 媣さの関係を, 図-28に圧縮強度とすり減り深さの 関係を示す。

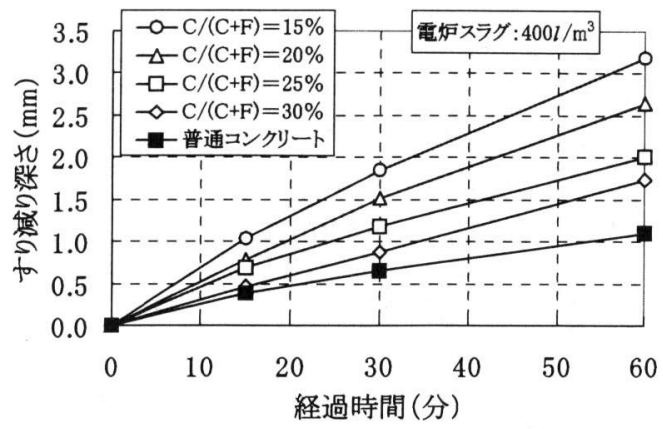

図-26 すり減り深さの経時変化

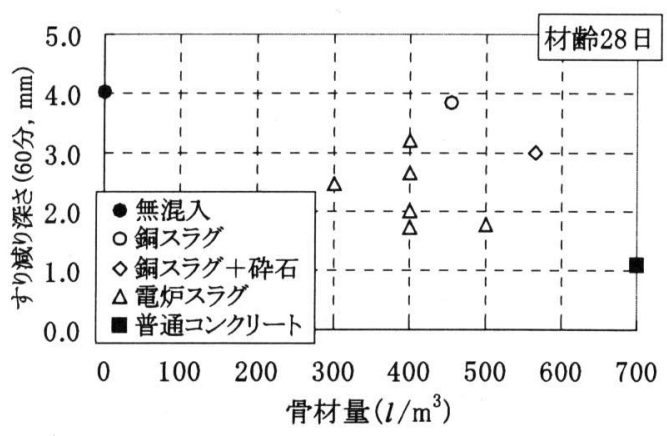

図-27骨材量とすり減り深さの関係

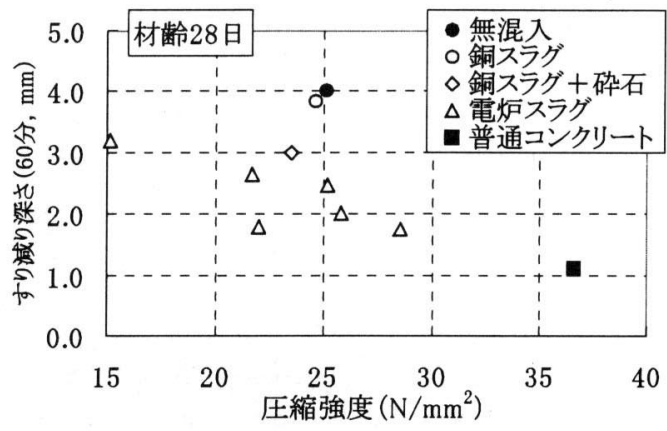

図-28 圧縮強度とすり減り深さの関係

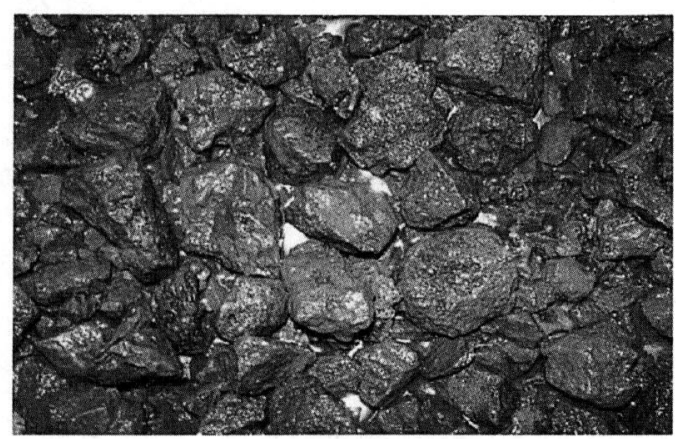

写真-2＼cjkstart発錆状況（電炬スラグ） 


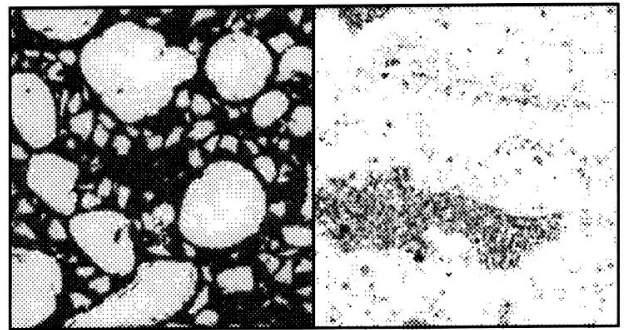

写真-3 水酸化カルシウムの分布 (左 : コンクリート, 右 : 石炭灰硬化体)

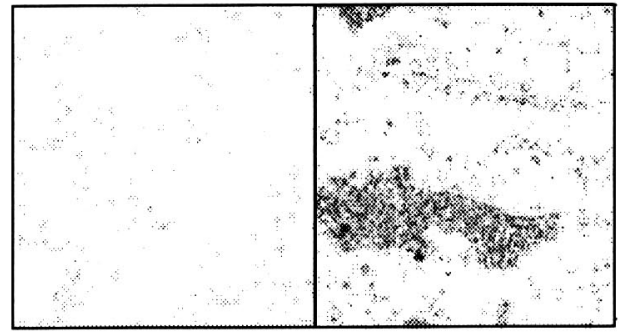

写真-4 エトリンガイトの分布

(左 : コンクリート, 右 : 石炭灰硬化体)

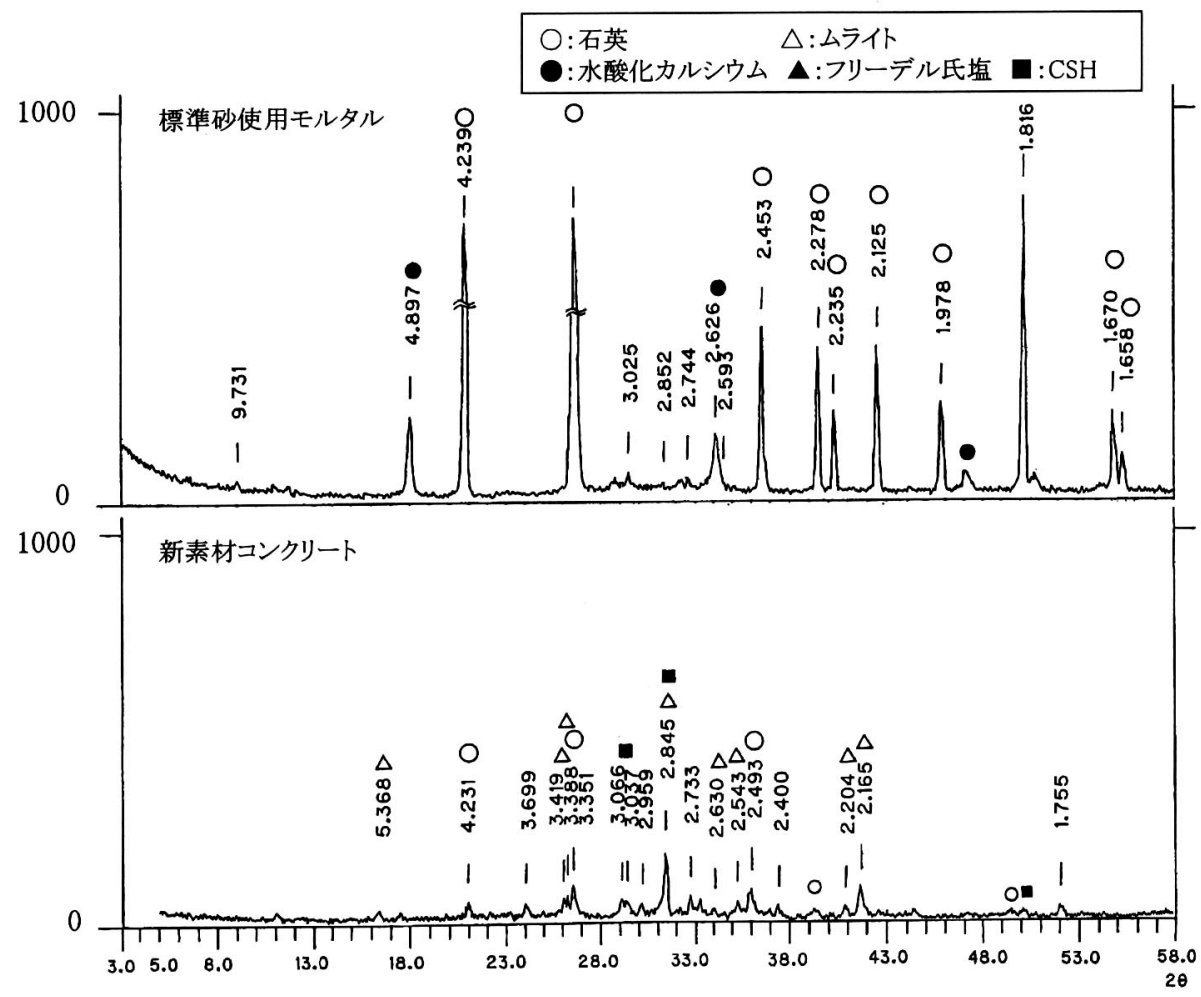

図-29 X線解析結果

石炭灰硬化体は骨材の混入によってすり減り抵抗 性が改善される傾向があることがわかる．スラグ骨 材を混入する場合は普通コンクリートよりも骨材量 が少なくなるため, その分すり減り抵抗性の改善幅 も小さくなる. しかしながら，セメント添加量を大 きくしてマトリックスの圧縮強度を増加させること により, 普通コンクリートと同等の抵抗性にまで改 善できることが確認できる．また，骨材種類による 違いは，今回の実験の範囲においては銅スラグより も電炬スラグの方が, すり減り抵抗性の改善に有効 である傾向がみられた.

\section{c) 発錆に対する評価}

金属スラグの海水での乾湿繰返しを実施し，目視 でスラグからの発錆状況を確認した. 写真-2 の赤 褐色部分が発錆箇所である. スラグはガラス化して おり，また，発錆はスラグ全体の表面積の $5 \%$ 以下 に収まることがわかった。また 1 年の長期間海面上 で暴露した供試体に発錆していないことからも，石 炭灰による発錆防止効果が期待でき，発錆によるコ ンクリートの膨張破壊などの影響は生じないものと 考えられる.

以上の各耐久性に対する評価を総括すると，石炭 
灰硬化体は密度向上により強度を得るもので, 現状 では空気量調整を行わず，実績空気量が 1.0 $2.0 \%$ であるため, 凍結融解抵抗性の解明が今後の 課題である. しかし，凍結融解作用を比較的受けな い箇所への適用を想定すれば特に問題はないと考え られる.

\section{(4) 硬化反応の形態等}

写真-3 に水酸化カルシウムの分布, 写真-4 にエ トリンガイトの分布を示す. この写真において, 色 の濃く見える部分がその鉱物が多く含まれているこ とを示す. 图-29にX線解析結果を示す.

この写真からわかるように, 石炭灰硬化体は通常 のコンクリートと比較し, ポゾラン反応により水酸 化カルシウムを消費していることが懸念されるが, エトリンガイトの形成量も少ないことから，カルシ ウム水和物を多く形成している.

また硬化体を粉砕して，「土壌污染に関わる環境 基準 ${ }^{12)} 」 に$ 記載された方法に基づき，各種の重金属 等の有害物質の溶出試験を実施したが，スラグおよ び石炭灰の種類に関わらず，現行基準で最も厳しい 「土壌污染に関わる環境基準」の值を満足する結果 であった。

\section{5. 配合設計手法}

\section{（1）配合設計の基本的な考元方}

配合設計は，目的とする密度によりスラグ混入量 を設定し, 締固め特性から水粉体比を決定する. 得 られた粉体総量を基に, 石炭灰原粉のセメント換算 係数により必要セメント量を決定し, 配合を確定す ることが可能である. 配合選定フローを図-30 に示 し, 具体的な配合設計方法を以下に述べる.

\section{（2）石炭灰原粉の品筫変動とその評価}

まず, 石炭灰は, 石炭の産地や発電所（燃焼温度 やボイラー形状等）によって，その品質が変動する ことが大きな問題点として挙げられる．図-31 に中 国電力侏の石炭火力発電所から発生する石炭灰原粉 における最適含水比および最大乾燥密度のヒストグ ラムを示す.

このように，石炭厑原粉はばらつきを持っており， 石炭灰原粉の品質変動による締固め特性の変化を評 価する必要がある. このため, 迅速且つ簡易に試験 を行うことができるモルタルフロー試験およびP口 一ト試験を実施し，これらの結果と締固め性能の指 標の一つでもあり配合設計に必要となる最適含水比
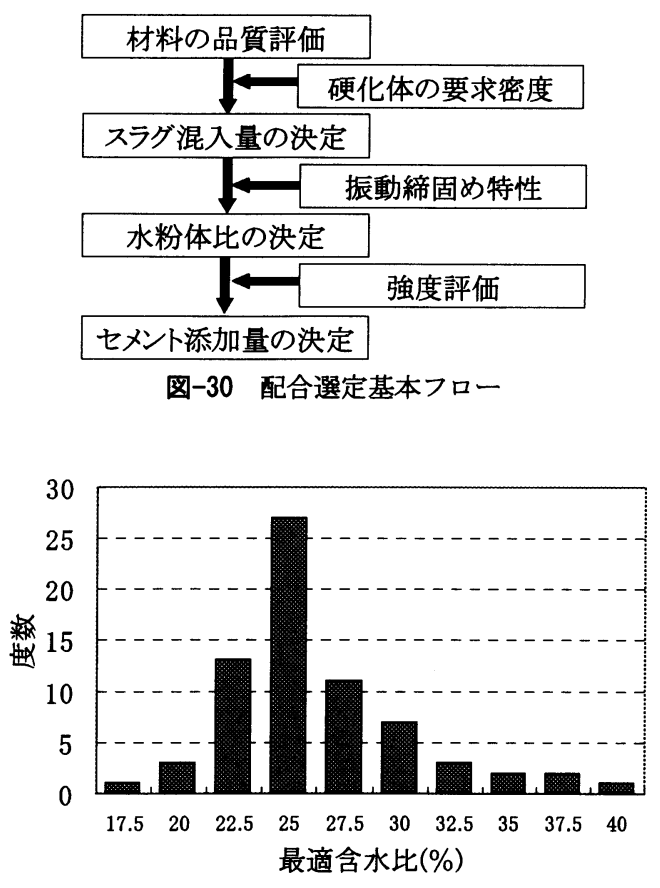

(a) 最適含水比の度数分布

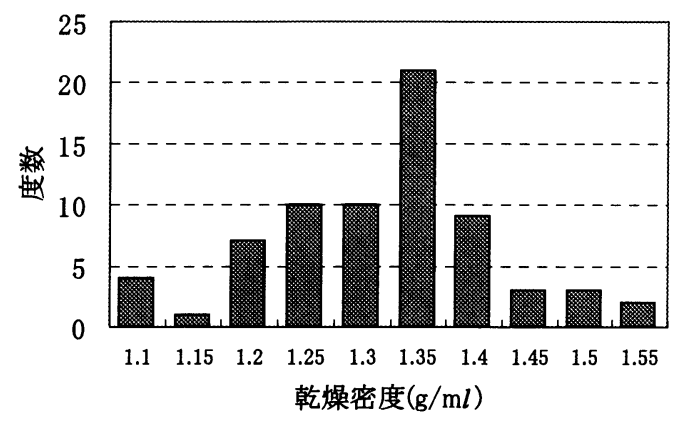

(b) 乾燥密度の度数分布

图-31 石炭灰原粉の品質変動

との関係を求めた.

図-32 にフロー值が $140 \mathrm{~mm}$ となる水粉体比 $\left(W_{140}\right)$ と最適水粉体比 $\left(W_{\mathrm{opt}}\right)$ の関係を, 図-33に 拘束水比 ${ }^{13)}$ と最適水粉体比の関保を示す. また, 図-34 にPロート流下時間が 20 秒となる水粉体比 $\left(W_{20}\right)$ と最大乾燥密度の関係を示す.

石炭灰は, $W_{140}$ および拘束水比と最適水粉体比, $W_{20}$ と最大乾燥密度の関係において高い相関を持つ ことがわかる.

締固め密度が強度を支配する石炭灰硬化体におい て，この相関関倸を活用することで容易に最適水粉 体比や最大乾燥密度を推定することができる.

例えば, 式(3)のように最適水粉体比を简易な試 験結果から推定することができる. 


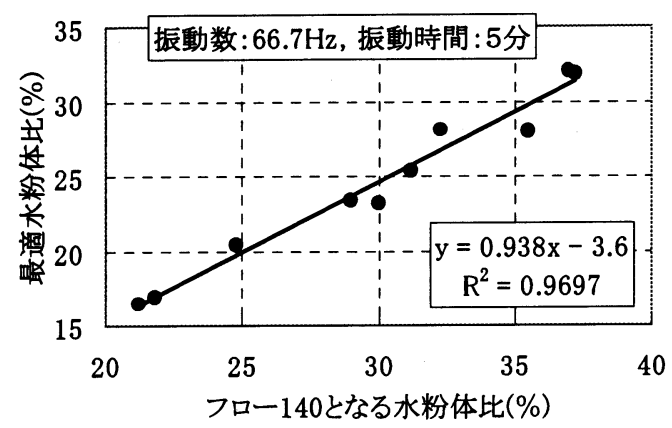

図-32 フロー140 水粉体比と最適水粉体比の関係

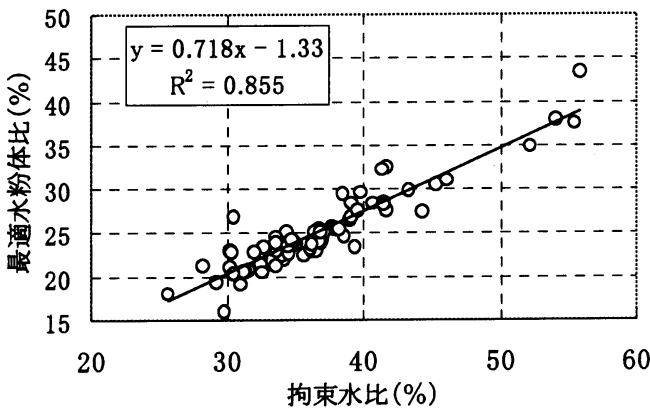

图-33 拘束水比と最適水粉体比の関保

$$
W_{\mathrm{opt}}=0.938 \cdot W_{140}-3.6
$$

ここに, $W_{\mathrm{opt}}$ : 最適水粉体比 $(\%)$

$W_{140}$ : モルタルフロー值 $140 \mathrm{~mm}$ となる 水粉体比 $(\%)$

(3) 水粉体比 W/ $(C+F)$ の決定

石炭灰硬化体の流体化する限界水粉体比を, 「66. $7 \mathrm{~Hz}$, 振幅 $1 \mathrm{~mm}$ で締め固めたとき, 流体化まで 要する時間が 5 分となる水粉体比」として定義する と, 石炭厕原粉の流体化限界水粉体比と最適水粉体 比は图-35に示すとおり，1：1の関係となる.

このため, 配合設計においては, 最適水粉体比 $\left(=W_{\mathrm{opt}}\right)$ と $W_{140}$ の関係を利用して, 式(4)により 係数 $\alpha$ を定義 (水粉体比が $W_{\text {opt }}$ の時 $\alpha=0, W_{140}$ の 時 $\alpha=1)$ し, 式(5)から最適な $\alpha(=\alpha$ opt $)$ に対 する水粉体比を推定することができる.ここで， $\alpha$ を無次元化して次式で与えることとする.

$$
\alpha=\frac{W /(C+F)-W_{\mathrm{opt}}}{W_{140}-W_{\mathrm{opt}}}
$$

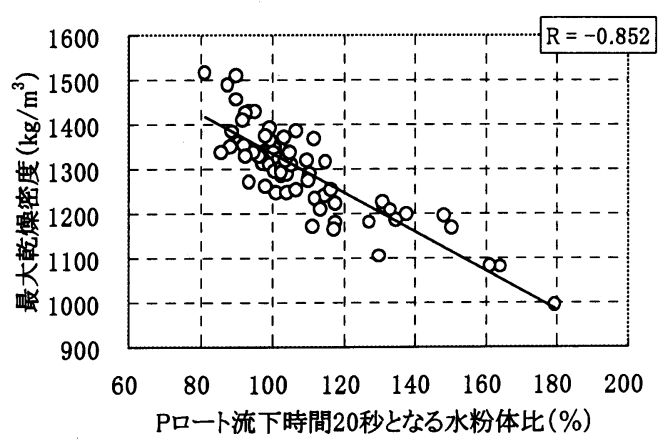

図-34 $W_{20}$ と最大乾燥密度の関倸

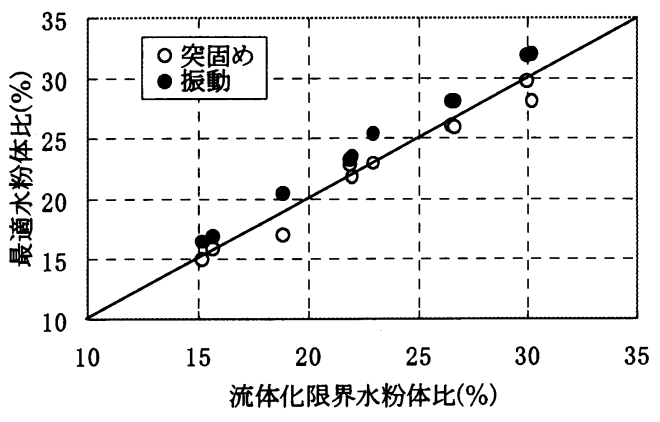

图-35 拘束水比と最適水粉体比の関保

ここに, $W$ : 任意の配合の水量 $\left(\mathrm{kg} / \mathrm{m}^{3}\right)$

$F$ : 任意の配合の石炭厕原粉量 $\left(\mathrm{kg} / \mathrm{m}^{3}\right)$

$W /(C+F)$ : 任意の水粉体比（\%）

式(4)で $\alpha$ に最適值 $\alpha_{\text {opt }}$ を用いると水粉体比は次 式で与えられることになる.

$$
W /(C+F)=W_{\text {opt }}+\alpha_{\text {opt }}\left(W_{140}-W_{\text {opt }}\right)
$$

ここに, $W /(C+F)$ : 最適配合の水粉体比（\%)

$$
\begin{aligned}
& C: \text { セメント量 }\left(\mathrm{kg} / \mathrm{m}^{3}\right) \\
& \alpha_{\text {opt }}: \text { 最適な係数 } \alpha
\end{aligned}
$$

この最適な $\alpha_{\text {opt }}$ は，前述の通り骨材混入条件や振 動条件により変化する.

図-36 に骨材混入量と $\alpha_{\text {opt }}$ の関係を，図-37 に振 動エネルギーと $\alpha_{\mathrm{opt}}$ の関係を示す.

これらの図から明らかなとおり，骨材の種類が決 まれば， $\alpha_{\text {opt }}$ は骨材混入量及び振動条件により 1 曲 線上にあることから，適切な $\alpha_{\mathrm{opt}}$ を選定することが できる. 


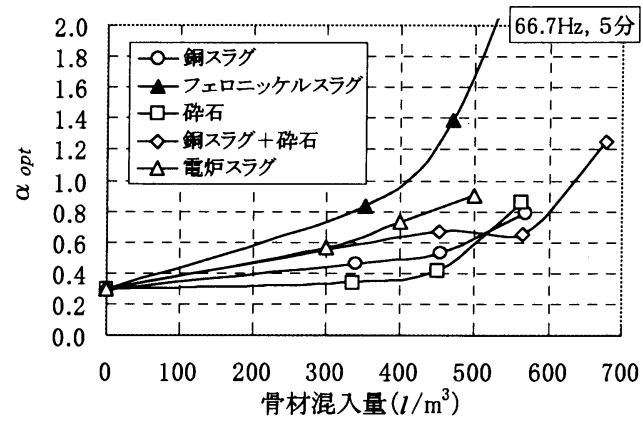

図-36 骨材混入量と $\alpha_{\text {opt }}$ の関係

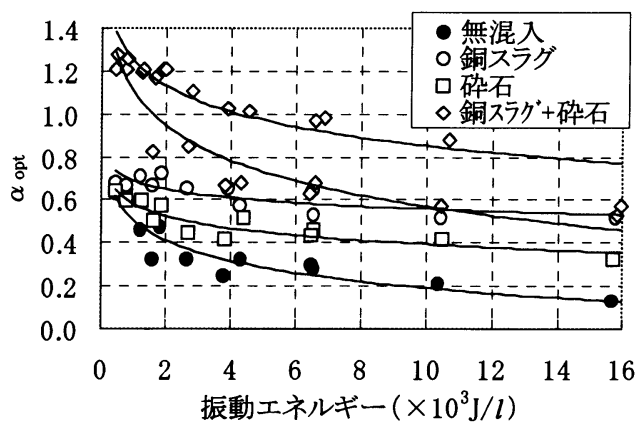

図-37振動エネルギーと $\alpha_{\mathrm{opt}}$ の関倸

\section{(4) 強度評価}

\section{a) 強度評価式およびセメント換算係数}

強度評価は，次の 2 つの仮定により石炭灰原粉の セメント換算係数による評価を行った.

(1)図-5に示寸骨材混入による最大乾燥密度低下の 少ない骨材混入範囲で使用するものとすれば，ペ 一スト部分の空隙量増大に伴う強度低下は微少で, その影響は無視できる.

(2)骨材混入によるペースト部分の強度低下は, 最適 含水比の増加分に相当する.

この仮定のもとに，石炭灰原粉のセメント換算係 数を水セメント比の概念から強度推定式により検討 を行った. 強度推定式は, 式(6)によった.

$$
\sigma_{28}=A \cdot \frac{(C+k \cdot F)}{W}+B
$$

\footnotetext{
ここに, $\sigma_{28}: 28$ 日材齢強度 $\left(\mathrm{N} / \mathrm{mm}^{2}\right)$

$C$ : 単位セメント量 $\left(\mathrm{kg} / \mathrm{m}^{3}\right)$

$F$ : 単位石炭灰原粉量 $\left(\mathrm{kg} / \mathrm{m}^{3}\right)$

$W:$ 単位水量 $\left(\mathrm{kg} / \mathrm{m}^{3}\right)$

$k:$ 石炭烣原粉のセメント換算係数

$A, B$ : 定数
}

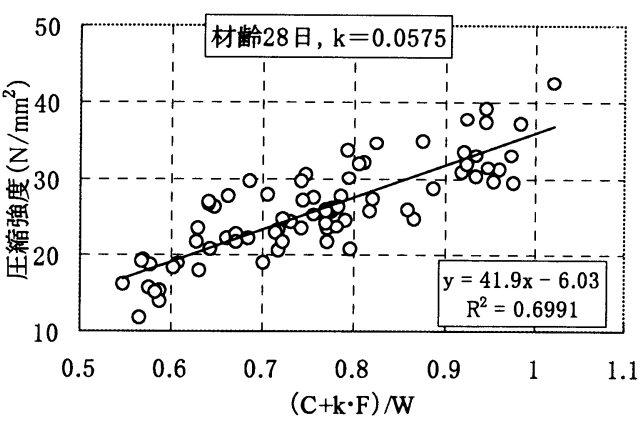

図-38 骨材混入量と $\alpha_{\text {opt }}$ の関俰

ここで，実験した全データを用いて重回帰分析を 行った結果を図-38 に示す.この結果から，式(6) で定義する石炭灰原粉のセメント換算係数は，材齢 28 日のとき約 $6 \%$ 程度で表すことができることが わかる.

$$
\begin{aligned}
& k=0.0575 \\
& A=41.9, \quad B=2.41 \\
& \text { ここに, 重相関係数 }: 0.74
\end{aligned}
$$

\section{b) 換算水結合材比と強度の関係}

このセメント換算係数を用いて換算水結合材比を 算出し，各種骨材を使った時の強度との関係を求め た結果を図-39に示す.

図に示すとおり，骨材の種類による差異が見られ， 銅スラグが最も低強度であり電炬スラグは無混入の 高密度硬化体と同等となる結果となった。これらに は, 最適含水比増加に伴うペースト部分の強度低下 は盛り込まれていることから，骨材の種類による強 度差は骨材の付着界面破壊の先行による破壊性状の 差異であると考えられる。

すなわち，銅スラグのような表面がガラス質であ るスラグは，骨材としての付着強度が低いものと考 えられる．また，骨材の粒度は，均一よりある程度 幅を持つ方が有利となる.

骨材の水和反応性については，電炉スラグの潜在 水和反応性による硬化作用が，特に微粉部分にある ものと考えられる，骨材混入の有無による差異は極 めて小さく, 骨材量の相違による影響は最適含水比 （=締固め密度）から得られる換算結合材水比で表 すことができる.

\section{(5)セメント添加量の決定}

以上のことから，使用する石炭厕原粉の品質およ び要求されるコンシステンシーから水粉体比 
$W /(C+F)$ が決定され, 骨材の種類・混入量および 振動条件による密度（=最適含水比）を考慮すれば, 式(6)から所要の強度が得られるようにセメント量 を決定することができる.

目標強度を $\sigma_{c k}$ として式(6)を展開すれば, セメ ント添加率は式(7)の通り算出することができる.

$$
\frac{C}{C+F}=\frac{\frac{F_{c r}-B}{A} \cdot \frac{W}{C+F}-k}{1-k}
$$

ここに, $C /(C+F):$ セメント添加率

$C$ : 単位セメント量 $\left(\mathrm{kg} / \mathrm{m}^{3}\right)$

$F$ : 単位石炭戻原粉量 $\left(\mathrm{kg} / \mathrm{m}^{3}\right)$

$W$ : 単位水量 $\left(\mathrm{kg} / \mathrm{m}^{3}\right)$

$\boldsymbol{k}$ : 石炭灰原粉のセメント換算係数

$$
(=0.0575)
$$

$F_{c r}$ : 目標強度 $\left(\mathrm{N} / \mathrm{mm}^{2}\right)$

$A, B:$ 定数 $(A=41.9, B=-6.0)$

この式により得られる配合をもとに, 実際の出荷 にあたっては，変動係数を設定することにより適切 な配合設計が可能となる.

\section{(6) 今後の展望}

配合設計手法の一提案を行ってきたが，今後は各 種金属スラグの特性を踏まえ，スラグを混入しない 硬化体に対するスラグ混入低減比, 或いはスラグの 品種・粒度等の諸条件を踏まえた算定図表（例えば, スラグ種類毎に補正係数を設定する）の作成によっ て，正確な配合設計が可能になるものと考えられる.

特に, 微粒分量や粗粒率などの骨材品質のばらつ きが石炭灰セメントコンクリートの品質に及ぼす影 響について明らかにすることは, 今後の最優先課題 であると思われる．このほか，スラグの品質におい ては, 水浸膨張性を持つなど化学的品質に留意する ものもあり，これに起因する硬化体の膨張破壊など の影響を把握することも必要である.

また, 実際のレディーミクストコンクリートプラ ント等での出荷データをもとに, 適切な変動係数の 設定が必要と考えられる.

\section{6. 結語}

本研究では, 石炭灰硬化体の密度の制御方法を検

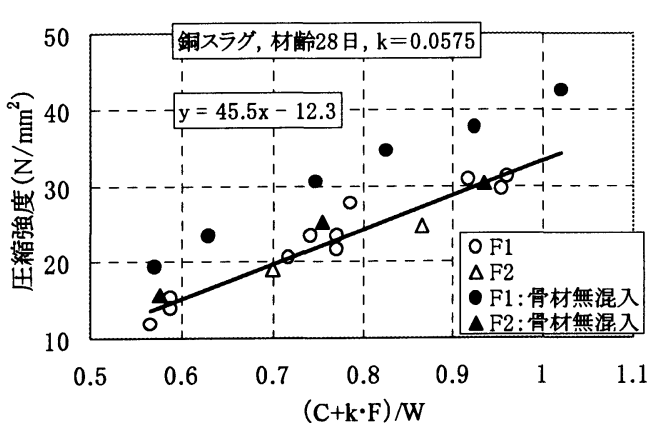

(a) 銅スラグ

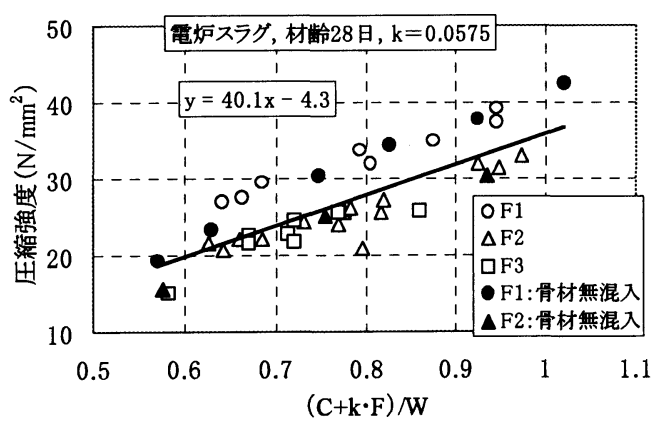

(b) 電炉スラグ

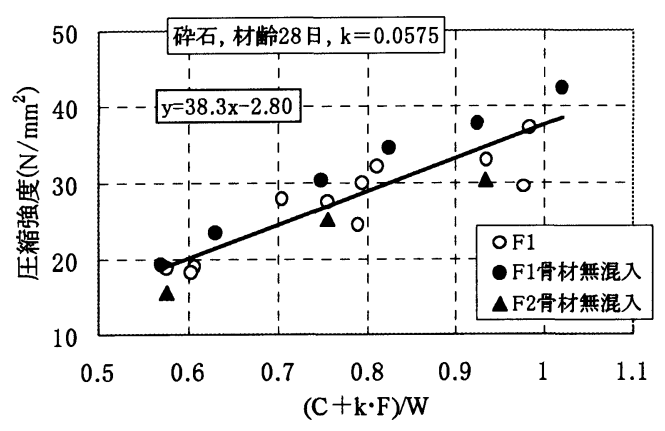

(c) 砕石

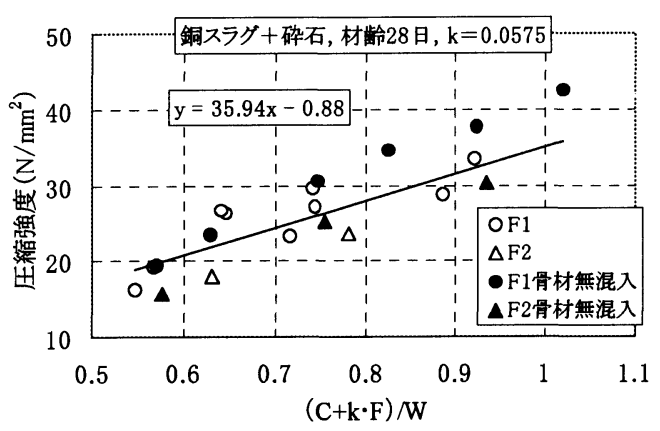

(d) 銅スラグと砕石

図-39 換算結合材水比と圧縮強度の関俰 
討することを目的に，密度の高い金属スラグの混入 を取り上げ，振動締固め特性、硬化後の物性に及ぼ す影響を調查した. 本研究で得られた結論をまとめ ると以下のようになる.

(1)骨材の混入による締固め特性は, 骨材混入に伴 い締固め性能は低下する傾向となるが，骨材実積率 に対し 50〜60\%の混入においては締固め性能を阻 害するものではない. この時の硬化体密度は, 銅ス ラグを活用すれば 2.6 程度であり, 重量コンクリー トとしても活用が可能である.

(2) 微粒分が多いと最適含水比が大幅に増大する. このため, スラグの使用に当っては, 微粒分を多量 に含まれないスラグを活用する必要がある.

(3) 本研究の石炭灰コンクリートは振動エネルギー による評価が可能であり，単位容積当り $5,000 \mathrm{~J} / l$ 程度のエネルギーを加えれば，いずれの骨材を用い た場合でも最大乾燥密度の最大值の $95 \%$ の密度を 得ることができる.

（4）圧縮強度は，骨材混入によって低下するが，セ メントの添加率によって調整が可能であり，その調 整幅も実用上セメント添加量の $5 \%$ 程度である.

(5)引張強度は, 骨材混入によって大幅に改善され, 通常のコンクリートと同等の引張強度を有している と考えられる.

(6) 変形特性は, 骨材混入によりヤング係数は大き くなるが，通常のコンクリートの $70 \sim 80 \%$ 程度で ある。

（7）応力ひずみ関係は，骨材混入により非線形性が 大きくなり，脆性的な破壊性状が改善される.

（8）長さ変化は，骨材混入によって低減し，普通コ ンクリートと同等以上に改善が図れる.

(9) 発錆については, スラグがガラス化しているこ とから、コンクリートの膨張破壊等は生じないレベ ルである.

(10) 強度と相関のある締固め特性（最適含水比, 最 大乾燥密度）とフロー試験で得られる $W_{140}$ やPロー 卜試験で得られる $W_{20}$ および拘束水比等と高い相関 関係を持つことから，簡易なこれらの試験により最 適含水比（=流体化限界水粉体比）の推定が可能で ある。

（11）配合設計上必要となる水粉体比は，骨材選定が できれば骨材混入量及び振動条件の相違による最適 な水粉体比を求めることができる.

（12）セメント量の決定は, 石炭灰のセメント換算係 数を活用することにより，硬化体の目標強度および 必要密度から選定することができる.

以上の知見から，金属スラグを使った石炭灰硬化 体は，コンクリートに代わる材料として活用が可能
であることがわかり，配合設計手法の方向性を見出 すことができた.

本研究では, 石炭灰硬化体を海洋構造物への適用 が図れることを目的とした研究を実施したため，空 気量の制御については今後の課題であり, 凍結融解 等の影響を受ける部分への活用は今後の課題として 残っている. 将来的には土木構造物全般に適用がで きるよう研究を進める必要があり, 空気量制御に関 する研究開発に現在取り組んでいる.

\section{参考文献}

1）福留和人, 長瀧重義, 坂本 守, 鈴木達雄, 喜多達 夫 : 最適含水比付近で練り混ぜたフライアッシュセ メント混合物の振動締固め特性に関する研究, 土木 学会論文集, No.627/V-4, pp.55-66, 1998.8 .

2) 國友宏俊 : 石炭灰に係る問題の所在と今後の検討の 在り方について, 石炭灰有効利用シンポジウム, 1998.5 .

3) 江原範明: 石炭灰の発生及び有効利用技術の開発状 況について, 石炭灰有効利用シンポジウム, 1998.5.

4) JS A 6201-1999 コンクリート用フライアッシュ, 1999.

5）矢原 隆, 和崎正令, 梅田俊夫 : 風化花崗岩を細骨材 としたコンクリート, コンクリートエ学年次論文報 告集, Vol.18, No.18, pp.429-434, 1996.

6) 土木学会, フライアッシュを用いたコンクリートの 施工指針(案), 1990.5 .

7) (財)土木研究センター, 石炭灰を利用した路盤・路 床・盛土材 ポゾテック, 1995.3.

8）堀内澄夫, 玉置克之, 尾上篤生, 後藤 茂, 清水勝公, 竹束正孝, 久野達彦, 若山茂己, 小田原卓郎 : フラ イアッシュを利用した自硬性軽量地盤, 第 33 回土質 工学シンポジウム, pp.45-50, 1988.

9）扇 正典, 浜田純夫, 松尾栄治, 齊藤 直: フライア シシュを RCC 細骨材として用いた場合の配合設計方 法に関する基礎的研究, コンクリート工学年次論文 報告集, Vol.22, No.2, pp.1147-1152, 2000.6.

10）綾野克紀, 阪田憲治, 柳 清 : 銅スラグを用いたコン クリートの凝結遅延特性に関する研究, 土木学会第 53 回年次学術講演会論文集, pp.468-469, 1998.10.

11) 土木学会: 土木材料実験指導書平成 11 年改訂版, p.32, 1999.

12）環境庁告知第 46 号「土壤污染に関わる環境基隻」, 1991.8 .

13) 岡村 甫, 前川宏一, 小沢一雅: ハイパフォーマンス コンクリート, pp.177-180，技報堂出版， 1993.

(2001.1.29 受付) 


\section{CHARACTERISTICS OF CONCRETE MIXED WITH COAL ASH AND METAL SLAGS}

\section{Tadashi SAITOH, Sumio HAMADA, Eiji MATSUO and Kazuto FUKUTOME}

The amount of coal ash has been increasing and development of the effective use has been urgently needed. Authors have been developping the production methods of concrete mixed with coal ash and metal slag. Laboratory tests show that the optimum mix design can be determined from the vibrating compaction energy and physical properties. The present study includes site placing tests which were conducted in order to confirm the applicability of coal ash to concrete of wave dissipating blocks. The preliminary laboratory tests were carried out to investigate the consistency, compactability, and duability of coal ash concrete. From the test results, the optimum mix design method of concrete mixed with coal ash and the compacting method were evaluated. 